\title{
BDNF Promotes Differentiation and Maturation of Adult-born Neurons through GABAergic Transmission
}

\author{
Emily G. Waterhouse, ${ }^{1}$ Juan Ji An, ${ }^{1}$ Lauren L. Orefice, ${ }^{1}$ Maryna Baydyuk, ${ }^{1}$ Guey-Ying Liao, ${ }^{1}$ Kang Zheng, ${ }^{2}$ Bai Lu, ${ }^{2}$ \\ and Baoji Xu${ }^{1}$ \\ ${ }^{1}$ Department of Pharmacology and Physiology, Georgetown University Medical Center, Washington, DC 20057 and ${ }^{2}$ Gene, Cognition and Psychosis \\ Program, National Institute of Mental Health-National Institutes of Health, Bethesda, Maryland 20892-3714
}

Brain-derived neurotrophic factor (BDNF) has been implicated in regulating adult neurogenesis in the subgranular zone (SGZ) of the dentate gyrus; however, the mechanism underlying this regulation remains unclear. In this study, we found that $B d n f$ mRNA localized to distal dendrites of dentate gyrus granule cells isolated from wild-type (WT) mice, but not from Bdnf $f^{k l o x / k l o x}$ mice where the long $3^{\prime}$ untranslated region (UTR) of $B d n f$ mRNA is truncated. KCl-induced membrane depolarization stimulated release of dendritic BDNF translated from long 3' UTR Bdnf mRNA in cultured hippocampal neurons, but not from short 3' UTR $B d n f$ mRNA. Bdnf $f^{\text {klox/klox }}$ mice exhibited reduced expression of glutamic acid decarboxylase 65 (a GABA synthase), increased proliferation of progenitor cells, and impaired differentiation and maturation of newborn neurons in the SGZ. These deficits in adult neurogenesis were rescued with administration of phenobarbital, an enhancer of $\mathrm{GABA}_{\mathrm{A}}$ receptor activity. Furthermore, we observed similar neurogenesis deficits in mice where the receptor for BDNF, TrkB, was selectively abolished in parvalbumin (PV)-expressing GABAergic interneurons. Thus, our data suggest that locally synthesized BDNF in dendrites of granule cells promotes differentiation and maturation of progenitor cells in the SGZ by enhancing GABA release, at least in part, from PV-expressing GABAergic interneurons.

\section{Introduction}

Adult hippocampal neurogenesis generates new neurons in the subgranular zone (SGZ) of the dentate gyrus throughout life and plays a key role in spatial discrimination (Dupret et al., 2008; Zhang et al., 2008). Hippocampal network activity and experience regulate adult neurogenesis at multiple stages from progenitor cell proliferation to maturation, survival, and synaptic integration of new neurons (Zhao et al., 2008; Ming and Song, 2011). Increasing evidence supports the notion that the neurotransmitter GABA is a key player in this process. GABAergic stimulation decreases the rate of proliferation (Tozuka et al., 2005; Chan et al., 2008). It has been shown that this effect is directly mediated through $\mathrm{GABA}_{\mathrm{A}}$ receptors on progenitor cells, and is due to GABA's excitatory action on neuronal differentiation and maturation (Tozuka et al., 2005; Ge et al., 2006).

Brain-derived neurotrophic factor (BDNF) is a potent modulator of neuronal development and synaptic transmission (Huang and Reichardt, 2001; Waterhouse and Xu, 2009). It promotes maturation of GABAergic inhibitory networks (Huang et

\footnotetext{
Received Feb. 14, 2012; revised Aug. 10, 2012; accepted Aug. 21, 2012.

Author contributions: E.G.W., J.J.A., L.L.O., M.B., G.-Y.L., and B.X. designed research; E.G.W., J.J.A., L.L.O., M.B., and G.-Y.L. performed research; K.Z. and B.L. contributed unpublished reagents/analytic tools; E.G.W., J.J.A., L.L.O., M.B., G.-Y.L., and B.X. analyzed data; E.G.W. and B.X. wrote the paper.

This work was supported by the National Institutes of Health Grants R01 NS050596 and R01 NS073930 (B.X.), F30 DK084717 (E.G.W.), and F31 NS074840 (L.L.O.). We thank Patrick Forcelli and Karen Gale for assistance in administration of phenobarbital.

Correspondence should be addressed to Dr. Baoji Xu, Department of Pharmacology and Physiology, Georgetown University Medical Center, 3900 Reservoir Road NW, Washington, DC 20057. E-mail: bx3@georgetown.edu.

B. Lu's present address: R\&D China, GlaxoSmithKline, Pudong, Shanghai 201203, China.

DOI:10.1523/JNEUROSCI.0709-12.2012

Copyright $\odot 2012$ the authors $\quad 0270-6474 / 12 / 3214318-13 \$ 15.00 / 0$
}

al., 1999; Hong et al., 2008). Furthermore, hippocampal network activity stimulates transcription of the $B d n f$ gene and translation of Bdnf mRNA (Patterson et al., 1992; Lau et al., 2010). These observations suggest that BDNF may serve as a link between neuronal activity and GABA-mediated effects on adult neurogenesis. In agreement with this view, considerable evidence links BDNF and adult neurogenesis (Lee et al., 2002b; Sairanen et al., 2005; Scharfman et al., 2005; Bergami et al., 2008; Chan et al., 2008; Li et al., 2008); however, these studies have reported conflicting results. While exogenous BDNF injected into the murine hippocampus was reported to increase proliferation (Scharfman et al., 2005), conditional knock-out mice lacking BDNF in mature neurons displayed increased proliferation as well (Chan et al., 2008). Reports of neurogenesis in Bdnf heterozygous mice have also been inconclusive, with some groups reporting increased proliferation (Sairanen et al., 2005) and others reporting decreased proliferation (Lee et al., 2002a).

One explanation for the discrepant findings concerning the role of BDNF in adult neurogenesis might lie in the complex regulation of BDNF expression. BDNF can be translated from two populations of mRNA species: with either a short or long $3^{\prime}$ untranslated region (3' UTR) (Timmusk et al., 1993; Ghosh et al., 1994). Short 3' UTR $B d n f$ mRNA is restricted to the soma, whereas long $3^{\prime}$ UTR Bdnf mRNA is also targeted to dendrites for local translation (An et al., 2008). The present studies investigated the relationship between dendritically synthesized BDNF and GABA with regard to their roles in adult neurogenesis. Our results suggest that BDNF translated from long $3^{\prime}$ UTR $B d n f$ mRNA in dendrites promotes maturation of adult-born neurons through parvalbumin (PV)-expressing GABAergic interneurons in the dentate gyrus. 


\section{Materials and Methods}

Animals. $B d n f^{k l o x /+}, B d n f^{L a c Z /+}$, and TrkB $B^{L a c Z /+}$ mice were previously described (Xu et al., 2000a; An et al., 2008; Baydyuk et al., 2011) and maintained on the C57BL/6 background. Bdnf ${ }^{\text {klox/klox }}$ mice and WT littermates were obtained from intercrosses of $B d n f^{k l o x /+}$ mice. $B d n f^{+/-}$ mice were obtained from the The Jackson Laboratory and maintained on the C57BL/6 background. Mice of either sex were used in this study. All procedures described were approved by the Institutional Animal Care and Use Committee at Georgetown University and were in compliance with the National Institutes of Health $(\mathrm{NIH})$ guide for the care and use of laboratory animals. All animals were given free access to food and water and housed in a $12 \mathrm{~h}$ light/dark cycle.

Hippocampal neuronal culture. Mouse hippocampi were dissected from newborn pups, and the isolated brain tissues were digested with papain at $37^{\circ} \mathrm{C}$ for $1 \mathrm{~h}$ according to the manufacturer's instruction (Worthington Biochemical). Dissociated cells were plated onto $15 \mathrm{~mm}$ diameter coverslips coated with poly-D-lysine $(37.5 \mu \mathrm{g} / \mathrm{ml})$ and laminin $(2.5$ $\mu \mathrm{g} / \mathrm{ml}$ ). The cells were cultured first in the Neurobasal medium supplemented with $10 \%$ fetal bovine serum for $3 \mathrm{~h}$ and then in the Neurobasal medium containing $2 \%$ B27 supplement, $500 \mu \mathrm{M}$ glutamine, and $12.5 \mu \mathrm{M}$ glutamate. At $2 \mathrm{~d}$ in vitro (DIV), Ara-C was added to the medium to reach a final concentration of $1 \mu \mathrm{M}$. Rat hippocampal neurons were isolated from E18.5 Sprague Dawley embryos and were cultured at a density of $1.8 \times 10^{5}$ cells/well in 12-well plates, according to previously described procedures (Sala et al., 2000; An et al., 2008).

BDNF-expressing constructs. To generate BDNF-expressing constructs, we sequentially cloned the cytomegalovirus promoter, the mouse $B d n f$ coding region that had a sequence insert encoding the Flag epitope (DYKDDDDK), immediately after the sequence encoding the signal peptide and was extended at its $3^{\prime}$ end with a sequence encoding the Myc tag (EQKLISEEDL), and the mouse genomic sequence for the short Bdnf $3^{\prime}$ UTR (A) or the long Bdnf $3^{\prime}$ UTR $\left(A^{*} \mathrm{~B}\right)$ into pBluescript II KS (-) (Stratagene), thus generating $\mathrm{pBDNF}-\mathrm{A}$ and $\mathrm{pBDNF}-\mathrm{A}^{\star} \mathrm{B}$, respectively. We added one amino acid (Ala) between the $B d n f$ coding region and the Myc tag and two amino acids (AsnSer) to the $C$ terminus of the Myc tag. In $\mathrm{pBDNF}-\mathrm{A}^{\star} \mathrm{B}$, the first polyadenylation site was mutated from the sequence AATAAA to TTTTTT, and thus it only produces long $3^{\prime}$ UTR $B d n f$ mRNA.

In situ hybridization. Fluorescent in situ hybridization (FISH) and subsequent immunocytochemistry of cultured hippocampal neurons were performed as described previously (An et al., 2008). We used rabbit polyclonal antibodies against Prox1 (1:1000 dilution; Millipore) to mark dentate gyrus granule cells. Radioactive in situ hybridization was performed as described previously (Xu et al., 2003). In brief, mouse brains were dissected and frozen immediately in an isopentane-dry ice bath. Brains were sectioned at $10 \mu \mathrm{m}$ using a cryostat, and in situ hybridization was performed on sections using a ${ }^{35} \mathrm{~S}$-labeled antisense riboprobe derived from cDNA encoding BDNF. After hybridization and washes, sections were exposed to Kodak BioMax MR Hyperfilm. For each mouse, images from eight sections were scanned at $1200 \mathrm{dpi}$, and the optical density of in situ signal in the granule cell layer of the dentate gyrus was determined using NIH ImageJ software.

$B D N F$ ELISA. Hippocampi were dissected from $B d n f^{k l o x / k l o x}, B d n f^{+/-}$, and WT mice at $\sim 6$ weeks of age, weighed, and homogenized in an ice-cold lysis buffer consisting of $100 \mathrm{~mm}$ Tris- $\mathrm{HCl}, 2 \%$ bovine serum albumin (BSA), $1 \mathrm{~m} \mathrm{NaCl}, 4 \mathrm{~mm}$ EDTA, 2\% Triton X-100, and protease inhibitors, $\mathrm{pH} 7$ ). The lysates were kept on ice for $30 \mathrm{~min}$ and centrifuged at $12,500 \mathrm{rpm}$ at $4^{\circ} \mathrm{C}$ for $20 \mathrm{~min}$. Supernatants were recovered as hippocampal protein extract. The amount of BDNF in hippocampal protein extract was measured using the BDNF ELISA kit from Millipore.

Treatments. 5-Bromo-2'-deoxyuridine (BrdU) was administered intraperitoneally $(50 \mathrm{mg} / \mathrm{kg})$ three times, once every $2 \mathrm{~h}$, into mice either at 4 weeks of age (the activation study; Fig. 7), or at 6 weeks of age (the proliferation, differentiation, and maturation studies; see Figs. 3-6, $8-10)$. Phenobarbital was administered intraperitoneally $(80 \mathrm{mg} / \mathrm{kg})$ once a day for $3 \mathrm{~d}$ before BrdU administration. Kainate was administered intraperitoneally ( $35 \mathrm{mg} / \mathrm{kg}$ ) to 8 -week-old animals to induce seizures, 4 weeks after BrdU administration, and $2 \mathrm{~h}$ before being killed. All animals achieved at least grade 4 seizures in which rearing was observed (Racine et al., 1972).

Immunohistochemistry and Nissl stains. Mice were anesthetized with avertin and transcardially perfused with PBS and 4\% paraformaldehyde (PFA) sequentially. Brains were removed from the skull, postfixed in $4 \%$ PFA overnight, and soaked in 30\% sucrose. Coronal brain sections (50 $\mu \mathrm{m}$ ) were obtained from the whole rostrocaudal extent of the hippocampus using a sliding microtome. For nonfluorescent staining, sections were incubated with $10 \%$ methanol-3\% hydrogen peroxide in Trisbuffered saline (TBS) to quench endogenous peroxidases. $\mathrm{HCl}$ antigen retrieval was used for $\mathrm{BrdU}$ and $\mathrm{Ki}-67 \mathrm{immunostaining}\left(2 \mathrm{~N} \mathrm{HCl}\right.$ at $37^{\circ} \mathrm{C}$ for $1 \mathrm{~h}$ before blocking). After incubation with blocking buffer $(0.4 \%$ Triton X-100, 2.5\% BSA, and 10\% horse serum in TBS) for $1 \mathrm{~h}$, the sections were incubated with primary antibody diluted in blocking buffer overnight at room temperature. The following primary antibodies were used: rat anti-BrdU (1:500; Accurate Chemical), rabbit anti-Ki-67 (1: 100; Thermo-Scientific Fisher), mouse anti-NeuN (1:500; Millipore Bioscience Research Reagents), goat anti-NeuroD (1:500; Santa Cruz Biotechnology), mouse anti-Sox2 (1:250; Millipore), chicken anti-Tbr2 (1:100; Millipore), rabbit anti-cleaved caspase-3 (1:200; Cell Signaling Technology), goat anti-DCX (1:250; Santa Cruz Biotechnology), mouse anti-calretinin (1:1000; Millipore), mouse anti-calbindin (1:400; Sigma), rabbit anti-glial fibrillary acidic protein (GFAP) (1:400; Sigma), mouse anti-Arc (1:50; Santa Cruz Biotechnology), rabbit anti-Zif268 (1:1000; Santa Cruz Biotechnology), mouse anti-glutamic acid decarboxylase 65 (GAD65) (1:400; Boehringer Mannheim), guinea pig anti-presynaptic vesicular glutamate transporter 1(VGLUT1) (1:1000; Millipore), mouse anti-PV (1:2000; Sigma), rabbit anti-somatostatin (SOM) (1:1000; Immunostar), rabbit anti-neuropeptide Y (NPY) (1:2000; Sigma), and rabbit anti- $\beta$-galactosidase (1:2000; Cappel). After three washes in TBS, the sections were incubated with the appropriate secondary antibody in blocking buffer. For colocalization studies, the appropriate fluorescent secondary antibodies were used, followed by three washes, after which sections were mounted using gelvatol fluorescence mounting media. For nonfluorescent staining, the appropriate biotinylated secondary antibody, followed by the avidin-biotin-peroxidase complex (Vector Laboratories) was used according to the manufacturer's protocol. Sections were developed in $0.05 \% 3-3^{\prime}$-diaminobenzidine tetrahydrochloride (DAB) and $0.003 \%$ hydrogen peroxide in $0.1 \mathrm{~m}$ Tris- $\mathrm{HCl}, \mathrm{pH} 7.5$, mounted onto slides, dehydrated, and coverslipped with DPX. Nissl staining was performed by submerging mounted sections in cresyl violet for 20 min before dehydration.

Quantitative analysis. Stereological counts of DAB-labeled cells were performed using Stereo Investigator software (MicroBrightField). Twelve series of brain sections were taken, and all sections from one well containing the whole rostrocaudal extent of the dentate gyrus were analyzed. The granule cell layer was outlined using a $20 \times$ objective and all stained cells within the outlined area were counted using a $60 \times$ objective to calculate cell density. Total dentate gyrus volume was extrapolated from these data. Pictures for colocalization quantification were acquired using a confocal microscope with a $40 \times$ oilimmersion lens. GAD65 and VGLUT1 staining intensities in the SGZ were measured using NIH ImageJ software. A box was drawn around the first two cell layers of the granule cell layer adjacent to the hilus and staining intensity was quantified.

Statistical analysis. All data are expressed as mean \pm SEM. Data were analyzed using an unpaired Student's $t$ test.

\section{Results}

\section{The long $B d n f 3^{\prime}$ UTR is required for dendritic localization of $B d n f$ mRNA in dentate gyrus granule cells}

It has been shown that $B d n f$ mRNA localizes to the molecular layer of the dentate gyrus (Lau et al., 2010) and that the long 3' UTR is necessary for localization of $B d n f$ mRNA to the dendrites of cortical and hippocampal pyramidal neurons (An et al., 2008). In this study we used $B d n f^{k l o x / k l o x}$ mice to determine whether the long $3^{\prime}$ UTR is also required for dendritic localization of $B d n f$ mRNA in dentate gyrus granule cells. In $B d n f^{k l o x / k l o x}$ mice, the vast 
majority of the long $B d n f 3^{\prime}$ UTR sequence is removed due to an insertion of SV40 polyadenylation signals in the $B d n f$ locus (An et al., 2008). We cultured neurons isolated from hippocampi of newborn WT and Bdnf klox/klox mice. Seven days later, we performed FISH using riboprobes derived from the $B d n f$ coding region and immunocytochemistry with an antibody against transcription factor Prox1 to mark granule cells in these cultures (Fig. 1A). Quantification of in situ hybridization signal showed that $B d n f$ mRNA localized to dendrites of WT granule cells and that this dendritic localization was significantly diminished in $B d n f^{k l o x / k l o x}$ granule cells (Fig. $1 A, B$ ), indicating that the long $B d n f 3^{\prime}$ UTR is required for dendritic localization of $B d n f$ mRNA in dentate gyrus granule cells.

\section{Neuronal activity stimulates release of dendritic BDNF derived from long $3^{\prime}$ UTR $\boldsymbol{B} \boldsymbol{d} \boldsymbol{n} \boldsymbol{f}$ mRNA}

We generated two BDNF-expressing constructs, pBDNF-A and $\mathrm{pBDNF}^{\star} \mathrm{A}$, where a BDNF-coding sequence was linked to the genomic sequence for either the short $(\mathrm{A})$ or long $\left(\mathrm{A}^{\star} \mathrm{B}\right)$ mouse $B d n f 3^{\prime}$ UTR (Fig. 2A). The encoded BDNF contains a Myc tag at its $\mathrm{C}$ terminus, so that the Myc tag marks both mature BDNF and proBDNF. To test whether activity stimulates release of dendritically synthesized BDNF, we transfected hippocampal neurons with either pBDNF-A (expressing short 3' UTR Bdnf mRNA) or pBDNF-A*B (expressing long $3^{\prime}$ UTR $B d n f$ mRNA) at $7 \mathrm{DIV}$ and applied $50 \mathrm{~mm} \mathrm{KCl}$ or vehicle to cultures at $10 \mathrm{DIV}$ for $30 \mathrm{~min}$ at $37^{\circ} \mathrm{C}$. Myc immunocytochemistry revealed that, in the absence of $\mathrm{KCl}, \mathrm{BDNF}$ levels were lower in cell bodies and higher in dendrites in neurons expressing long 3' UTR $B d n f$ mRNA than in neurons expressing short 3' UTR Bdnf mRNA (Fig. $2 B, C$ ), indicating that a portion of long $3^{\prime}$ UTR $B d n f$ mRNA molecules are transported to dendrites and translated there. Following $\mathrm{KCl}$ treatment, BDNF levels in neurons overexpressing long 3' UTR Bdnf mRNA were significantly reduced in dendrites, but not in somata, compared with unstimulated neurons (Fig. $2 \mathrm{~B}, \mathrm{C}$ ). No changes in BDNF levels were observed following $\mathrm{KCl}$ treatment in either dendrites or somata of neurons overexpressing short 3' UTR $B d n f$ mRNA (Fig. $2 B, C$ ). These results suggest that neuronal activity stimulates release of dendritic BDNF translated from long $3^{\prime}$ UTR $B d n f$ mRNA.

\section{Long 3' UTR Bdnf mRNA regulates adult neurogenesis}

To determine whether adult neurogenesis is altered in $B d n f^{\text {klox/ }}$ klox mice that lack long 3' UTR Bdnf mRNA, we first assessed proliferation in these animals by measuring the number of cells that incorporate the DNA synthesis marker BrdU. Mice were injected with BrdU intraperitoneally at 6 weeks of age and killed at varying time intervals postinjection: $1 \mathrm{~h}, 24 \mathrm{~h}, 3 \mathrm{~d}$, 1 week, 3 weeks, 6 weeks, or 12 weeks. We were surprised to find that $24 \mathrm{~h}$ following BrdU administration $B d n f^{k l o x / k l o x}$ mice had a 1.7-fold increase in the density of BrdU-labeled cells in the den- tate gyrus compared with WT controls (Fig. $3 A, B$ ). In addition, $B d n f^{k l o x / k l o x}$ mice had a modest but significant increase in the density of BrdU-labeled cells at the $1 \mathrm{~h}$ time point compared with WT controls (Fig. 3B). As we found no significant difference in the volume of the dentate gyrus between WT and $B d n f^{k l o x / k l o x}$ mice (Fig. 3C), the density increase indicates that proliferation of SGZ precursors is enhanced in the absence of long 3' UTR Bdnf mRNA. However, $B d n f^{k l o x / k l o x}$ mice showed no significant differences in the number of BrdU-labeled cells at all other time points analyzed, from $3 \mathrm{~d}$ to 12 weeks (Fig. $3 B$ ). These results suggest that over the course of $24 \mathrm{~h} B d n f^{k l o x / k l o x}$ mice were accumulating more BrdU-labeled cells compared with WT mice, and that the extra newly labeled BrdU-positive cells that were present at $24 \mathrm{~h}$ had died off by 1 week postlabeling. In addition, we found no significant difference in granule cell layer volume between WT and $B d n f^{k l o x / k l o x}$ mice (Fig. 3D,E), indicating that the increase of newborn cells at early time points was temporary and ultimately did not result in altered dentate gyrus morphology.

To test if the SGZ proliferative population was expanded in $B d n f^{k l o x / k l o x}$ mice, we counted the number of cells positive for Ki-67, an endogenous marker for actively cycling cells, and found that $B d n f^{k l o x / k l o x}$ mice had a trend toward an increased proliferative population compared with WT controls; however, this value was not significant (Fig. $3 F, G$ ). We then investigated whether our finding of a transient increase in BrdU-labeled cells might result from reduced $B d n f$ expression in the dentate gyrus of $B d n f^{k l o x / k l o x}$ mice. To explore this possibility, we conducted radioactive in situ hybridization on brain sections from WT and $B d n f^{\text {klox/klox }}$ mice using a probe against the $B d n f$ coding region. This experiment revealed a modest but significant decrease in levels of dentate 
A

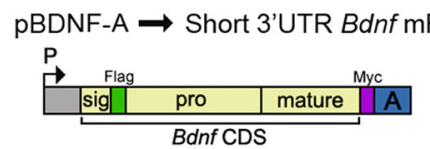

B
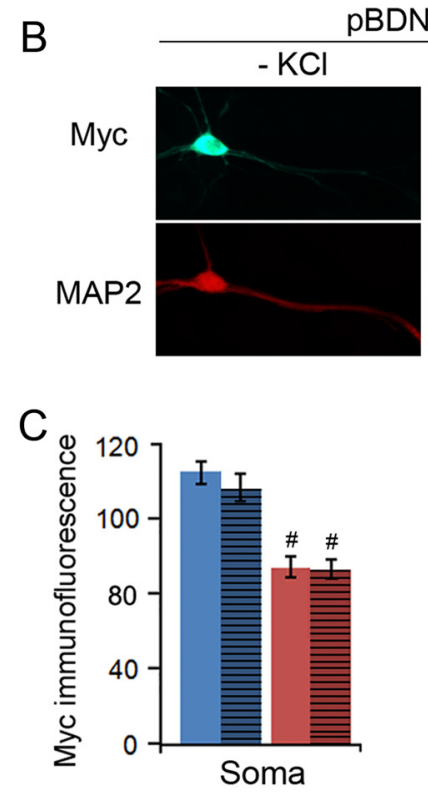
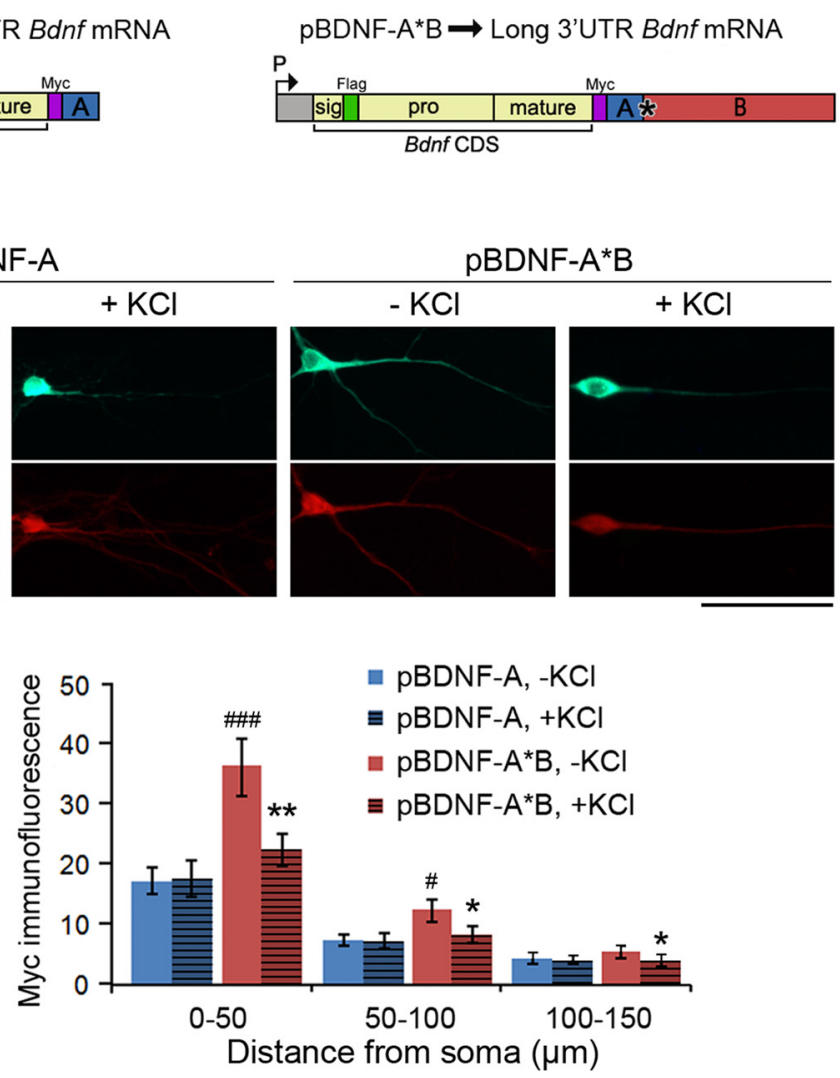

Figure 2. Activity stimulates BDNF release from dendrites of neurons overexpressing long 3' UTR Bdnf mRNA. $A$, Diagrams of constructs that express either mouse short 3' UTR Bdnf mRNA (pBDNF-A) or mouse long $3^{\prime}$ UTR BdnfmRNA (pBDNF-A*B). P, promoter; CDS, coding sequence. $B$, Representative immunocytochemistry images with antibodies to Myc and MAP2 for 10 DIV neurons transfected with either pBDNF-A or pBDNF-A*B that were either unstimulated or stimulated with $50 \mathrm{~mm} \mathrm{KCl} \mathrm{for} 30$ min at $37^{\circ} \mathrm{C}$. Scale bar, $50 \mu \mathrm{m}$. $\mathrm{C}$, Levels of Myc-tagged BDNF in somata $(n=$ $18-25$ neurons/condition) or dendrites ( $n=16-18$ neurons/condition) of neurons at 10 DIV as represented in $B$. Error bars indicate SEs. Student'st test: ${ }^{*} p<0.05$ and ${ }^{* *} p<0.01$ when compared with unstimulated neurons transfected with the same construct; ${ }^{\#} p<0.05$ and ${ }^{\# \# \#} p<0.001$ when compared with neurons expressing short $3^{\prime}$ UTR Bdnf mRNA under the same stimulation condition.

gyrus Bdnf mRNA in $B d n f^{k l o x / k l o x}$ mice (Fig. $3 H, I$ ). This result is largely in agreement with the previous observation that $B d n f$ mRNA levels are normal in the $B d n f^{\text {klox/klox }}$ hippocampus, as revealed by Northern hybridization (An et al., 2008). Because it is difficult to dissect the dentate gyrus, we measured the concentration of BDNF in whole hippocampal lysates using ELISA, which revealed that $B d n f^{k l o x / k l o x}$ mice had a $48 \%$ reduction of total hippocampal BDNF compared with WT mice (Fig. $3 J$ ). These observations indicate that $B d n f^{k l o x / k l o x}$ mice exhibit reduced total BDNF levels.

$B d n f^{k l o x / k l o x}$ mice lack dendritic $B d n f$ mRNA because the long $B d n f 3^{\prime}$ UTR is truncated (Fig. 1). To determine whether the neurogenesis deficit observed in $B d n f^{k l o x / k l o x}$ mice is due to a lack of dendritic $B d n f$ mRNA or a general reduction in BDNF protein levels, we conducted a BrdU-labeling study of $B d n f$ heterozygous mice $\left(B d n f^{+/-}\right)$, which carry only one copy of the functional $B d n f$ allele. ELISA assays revealed a $36 \%$ reduction in hippocampal BDNF levels in $B d n f^{+/-}$mice ( $100 \pm 10 \%$ for WT vs $64 \pm 4 \%$ for $B d n f^{+/-}, p<0.01, n=6$ mice per genotype). Unlike $B d n f^{k l o x} / k l o x$ mice, $B d n f^{+/-}$mice still have long $3^{\prime}$ UTR $B d n f$ mRNA, and therefore retain pools of dendritic $B d n f$ mRNA. We found that $24 \mathrm{~h}$ after BrdU administration, $B d n f^{+/-}$mice did not show significant increases in BrdU-labeled cells compared with WT mice, but $B d n f^{d l o x / k l o x}$ mice did (Fig. $3 K$ ). Collectively, these observations suggest that the lack of dendritic $B d n f$ mRNA resulted in the drastic increase in BrdU-labeled cells in the first $24 \mathrm{~h}$ after BrdU administration in $B d n f^{\text {klox/klox }}$ mice. However, our results do not exclude the possibility that the additional decrease in total BDNF levels from $36 \%$ in $B d n f^{+/-}$mice to $48 \%$ in $B d n f^{k l o x / k l o x}$ mice may also contribute to the increased BrdU labeling.

Long $3^{\prime}$ UTR $B d n f$ mRNA promotes neuronal differentiation Our finding that $B d n f^{k l o x / k l o x}$ mice had a temporarily expanded pool of BrdU-labeled cells, which increased in magnitude from 1 to $24 \mathrm{~h}$ post-BrdU administration, suggests that long $3^{\prime}$ UTR $B d n f$ mRNA promotes differentiation of progenitor cells. We reasoned that if proliferative cells were not receiving proper neuronal differentiation signals, they would stay in the cell cycle longer and the BrdU-labeled population would expand. To determine whether $B d n f^{k l o x / k l o x}$ mice have differentiation deficits, we first evaluated cell-cycle exit of BrdU-labeled cells $3 \mathrm{~d}$ post-BrdU labeling in the dentate gyrus. Cells that remained in the cell cycle following that period would still express $\mathrm{Ki}-67\left(\mathrm{Ki}-67^{+} \mathrm{BrdU}{ }^{+}\right)$; however, cells that had exited the cell cycle would retain their BrdU labeling, but lose $\mathrm{Ki}-67$ expression $\left(\mathrm{BrdU}^{+}\right)$. We found that $B d n f^{k l o x / k l o x}$ mice did have impaired cell-cycle exit, such that a significantly higher percentage of cells that were BrdU positive also stained for Ki-67 in $B d n f^{k l o x / k l o x}$ mice compared with WT controls (Fig. 4A,B).

To further investigate neuronal differentiation deficits in $B d n f^{k l o x / k l o x}$ mice, we used a neuronal differentiation index. Three days after BrdU administration we colocalized BrdU and the neuronal marker NeuN in the dentate gyrus. If cells differentiated out of the cell cycle and into the neuronal phenotype, they would 

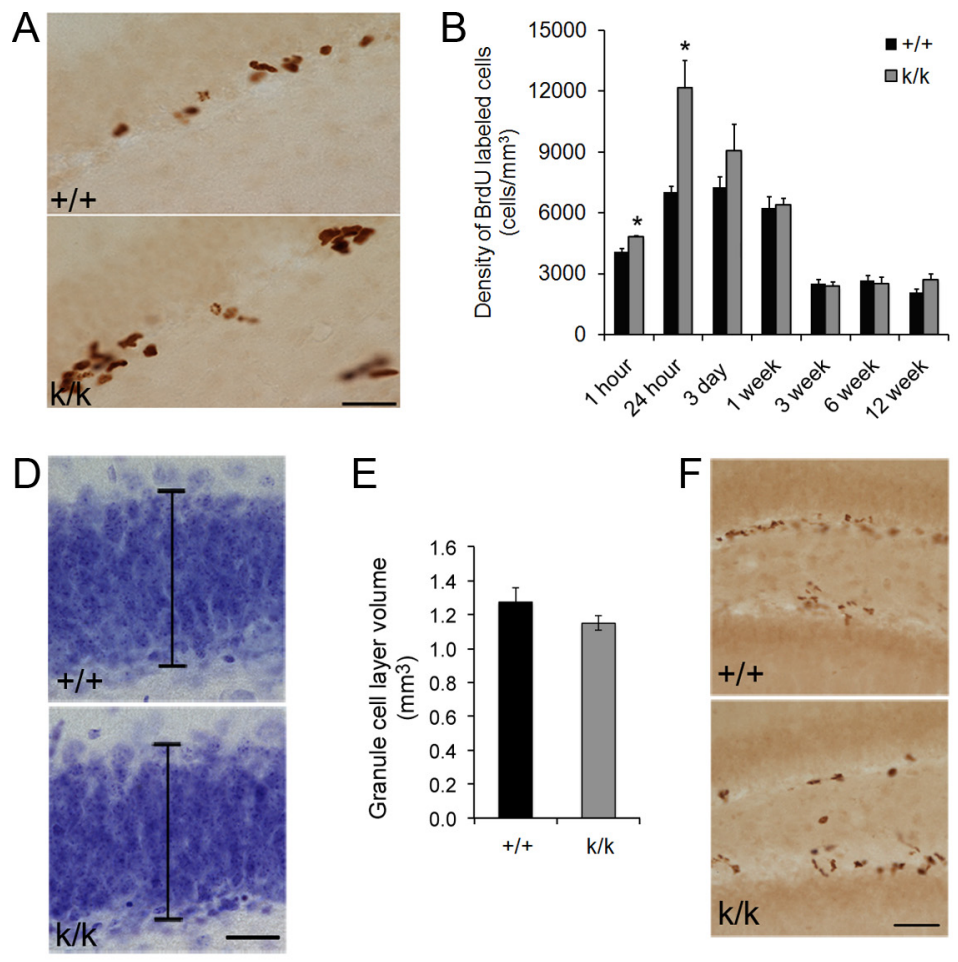

$\mathrm{H}$

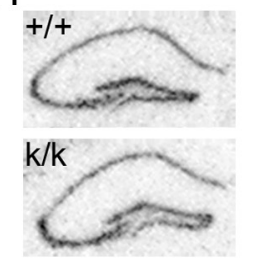

E

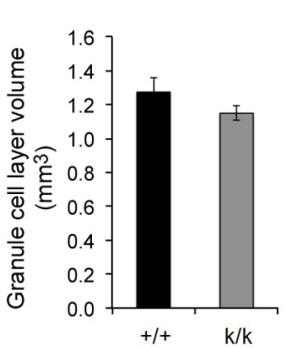

F

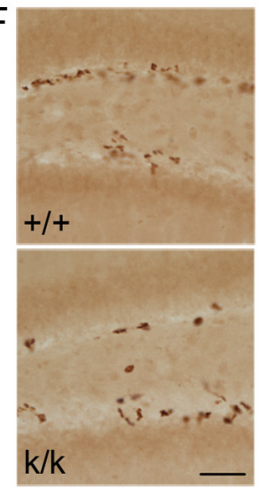

I

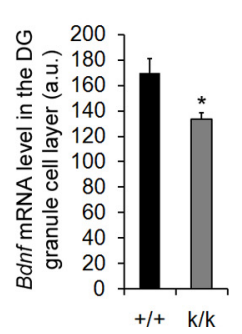

J

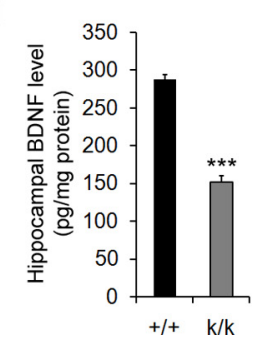

C

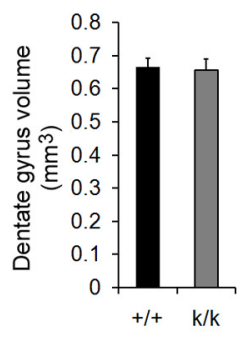

G

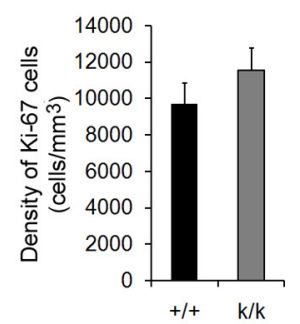

K

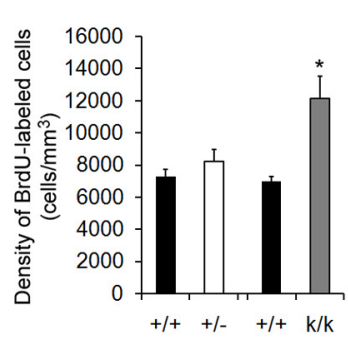

Figure 3. Long 3' UTR BdnfmRNA regulates adult neurogenesis. $A$, Representative images of BrdU immunostaining in the dentate gyrus $24 \mathrm{~h}$ post-BrdU injection of 6-week-old WT ( $+/+$ ) and $B d n f^{k l o x} / k l o x(k / k)$ mice. Scale bar, $50 \mu \mathrm{m}$. B, Quantification of the density of BrdU-immunoreactive cells in the dentate gyrus of $+/+$ and k/k mice. Mice were treated with BrdU at 6 weeks of age and killed at varying time intervals post-BrdU administration, from $1 \mathrm{~h}$ to 12 weeks $(n=4$ mice per group). Error bars indicate SEs. $C$, Quantification of the dentate gyrus volume of adult $+/+$ and $\mathrm{k} / \mathrm{kmice}$ ( $n=28$ mice per genotype). Error bars indicate SEs. D, Representative images of Nissl-stained dentate gyri in $+/+$ and $/ \mathrm{k}$ mice. Black bars represent the thickness of the granule cell layer. Scale bars, $50 \mu \mathrm{m}$. $\boldsymbol{E}$, Quantification of the granule cell layer volume of adult $+/+$ and $\mathrm{k} / \mathrm{k}$ mice $(n=3$ mice per genotype). Error bars indicate SEs. $\boldsymbol{F}$, Representative images of Ki-67 immunostaining in the dentate gyrus of 6-week-old +/+ and k/k mice. Scale bar, $50 \mu \mathrm{m}$. G, Quantification of Ki-67 ${ }^{+}$cells in the dentate gyrus of 6-week-old $+/+$and k/k mice. Error bars indicate SEs. $\boldsymbol{H}$, Representative images of radioactive in situ hybridization of $+/+$ and $\mathrm{k} / \mathrm{k}$ coronal brain sections. $\mathbf{I}$, Quantification of radioactive in situ hybridization signal in the granule cell layer of the dentate gyrus of $+/+$ and $\mathrm{k} / \mathrm{k}$ mice $(n=4$ mice per genotype). Error bars indicate SEs. J, ELISA analysis of hippocampal BDNF levels in 6 -week-old $+/+$ and k/k mice $(n=5$ mice per genotype). Error bars indicate SEs. $\boldsymbol{K}$, Quantification of the density of BrdU-immunoreactive cells in the dentate gyrus of $+/+, B d n f^{+/-}(+/-)$, and k/k mice. Mice were treated with BrdU at 6 weeks of age and killed $24 \mathrm{~h}$ postinjection. Error bars indicate SEs. Student's $t$ test: ${ }^{*} p<0.05 ;{ }^{* * *} p<0.001$.

costain for both NeuN and $\mathrm{BrdU}\left(\mathrm{NeuN}^{+} \mathrm{BrdU}^{+}\right)$; however, if cells had not attained the neuronal phenotype, they would only contain $\mathrm{BrdU}\left(\mathrm{BrdU}^{+}\right)$. We found that $B d n f^{\text {dlox } / k l o x}$ mice had a significantly lower percentage of BrdU-positive cells that also stained for NeuN (Fig. $4 C, D$ ), indicating that $B d n f^{k l o x / k l o x}$ mice display deficits in neuronal differentiation. Collectively, these data argue that long $3^{\prime}$ UTR $B d n f$ mRNA promotes progenitor cell differentiation out of the cell cycle and into the neuronal phenotype.

\section{Long 3' UTR Bdnf mRNA promotes differentiation of late- stage progenitor cells}

There are three types of proliferative progenitor cells in the SGZ. Radial glia-like primary progenitor cells (type 1) divide slowly to produce intermediate progenitor cells (type 2), which divide rapidly to generate type 3 progenitor cells, neuroblasts (Ming and Song, 2011). Type 1 and early stage type 2 progenitor cells express Sox 2 ; type 2 and type 3 progenitor cells express Tbr2; and neuro- blasts and immature neurons express doublecortin (DCX) (Ming and Song, 2011). To determine at what progenitor stage the deficit in differentiation occurs in $B d n f^{\text {klox/klox }}$ mice, we evaluated colocalization of BrdU with Sox2, Tbr2, and DCX 24 h postBrdU labeling (Fig. 5A-C). We expected to see an increase in colocalization in the progenitor population that was receiving decreased differentiation signaling, because they were accumulating instead of differentiating. We found that $B d n f^{k l o x / k l o x}$ mice had a normal percentage of BrdU-positive cells that expressed Sox2, a significantly lower percentage of BrdU-positive cells that expressed Tbr2, and a significantly higher percentage of BrdUpositive cells that expressed DCX (Fig. 5D). These results indicate that the differentiation deficits we observed in $B d n f^{k l o x / k l o x}$ mice are likely due to impediments in differentiation of late-stage progenitor cells into neurons, thus causing an accumulation of $\mathrm{DCX}^{+} / \mathrm{BrdU}^{+}$cells. In addition, we found a significant decrease in the percentage of $\mathrm{BrdU}^{+}$cells that were $\mathrm{Tbr} 2^{+}$. This result may indicate that signaling, which stimulates the differentiation 

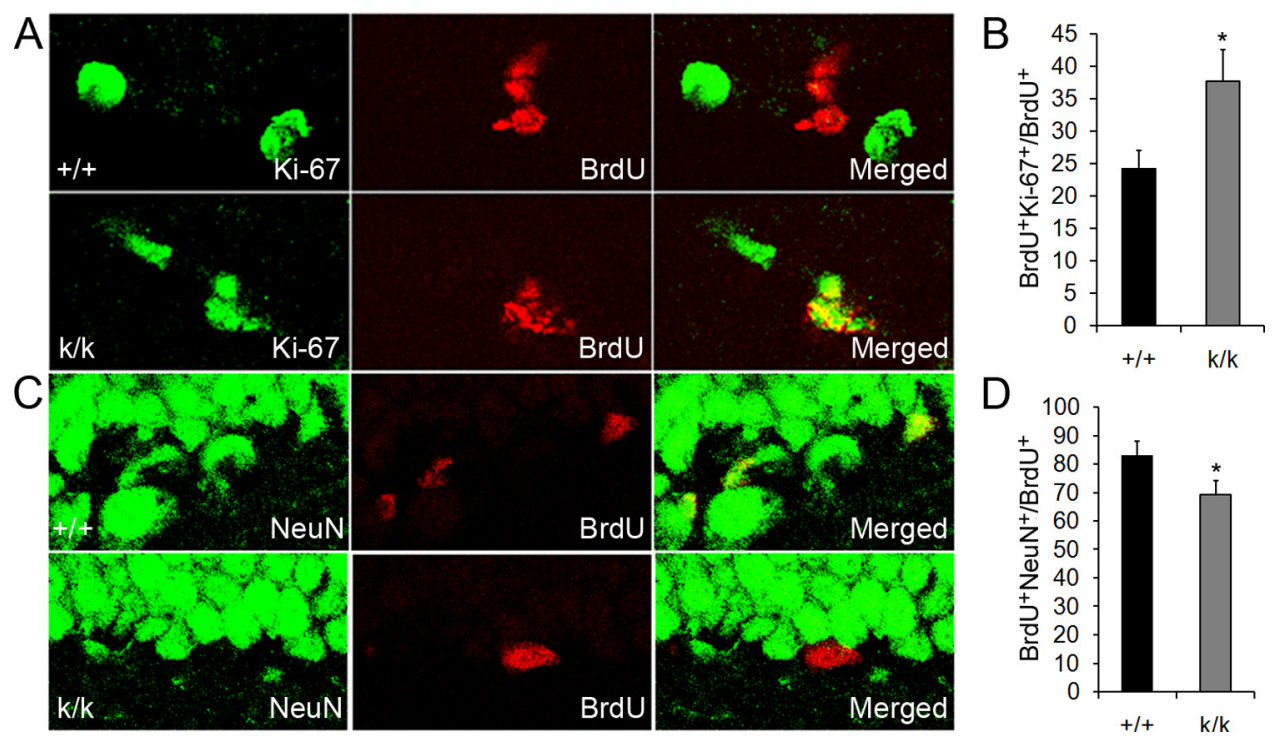

Figure 4. Long 3' UTR Bdnf mRNA promotes neuronal differentiation. A, Representative confocal images of BrdU colocalized with Ki-67 in WT (+/ +) and Bdnflox/klox (k/k) mice. Mice were treated with BrdU at 6 weeks of age and killed $3 \mathrm{~d}$ postinjection for immunohistochemistry. B, Quantification of BrdU and Ki-67 colocalization. The graph denotes the percentage of BrdU ${ }^{+}$cells that also express Ki-67 ( $n=4$ mice per genotype). Error bars indicate SEs. C, Representative confocal images of BrdU colocalized with NeuN in $+/+$ and k/kmice. Mice were treated with BrdU at 6 weeks of age and killed $3 \mathrm{~d}$ postinjection for immunostaining. $D$, Quantification of BrdU and NeuN colocalization. The graph denotes the percentage of BrdU ${ }^{+}$cells that also express NeuN $(n=4$ mice per genotype). Error bars indicate SEs. Student's $t$ test: ${ }^{*} p<0.05$.

A
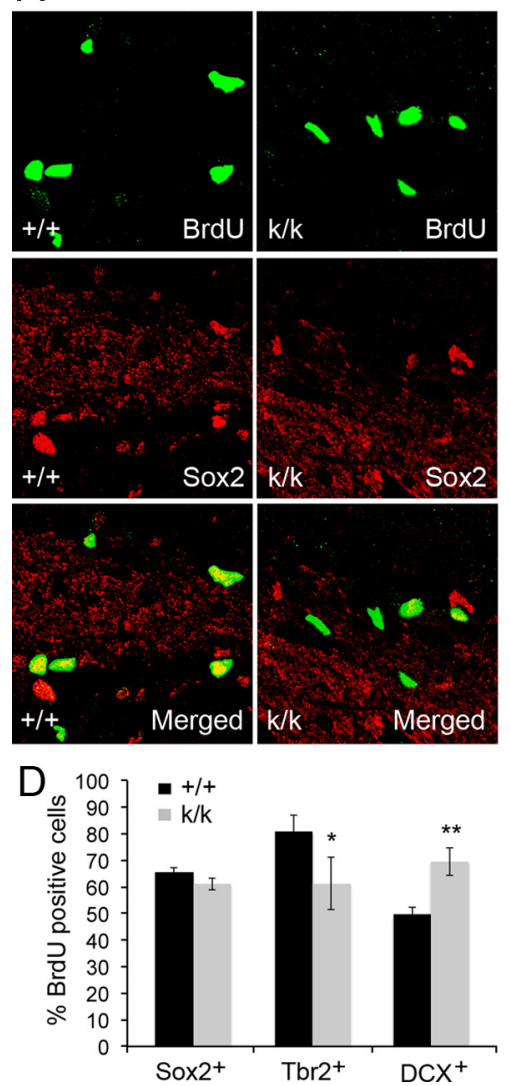

B
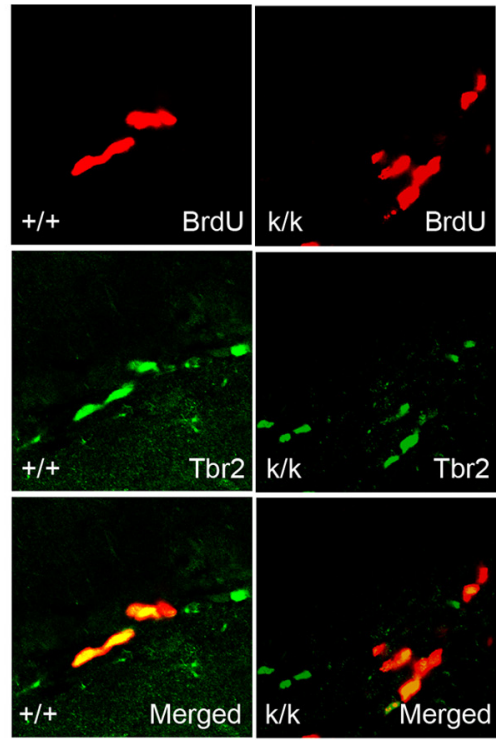

$\mathrm{E}$

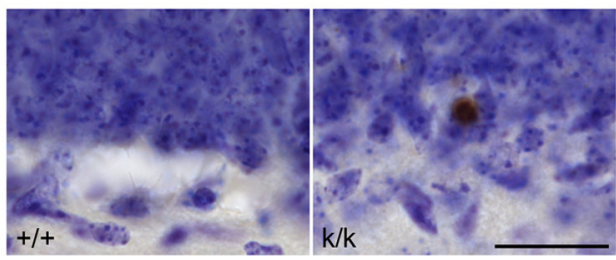

C
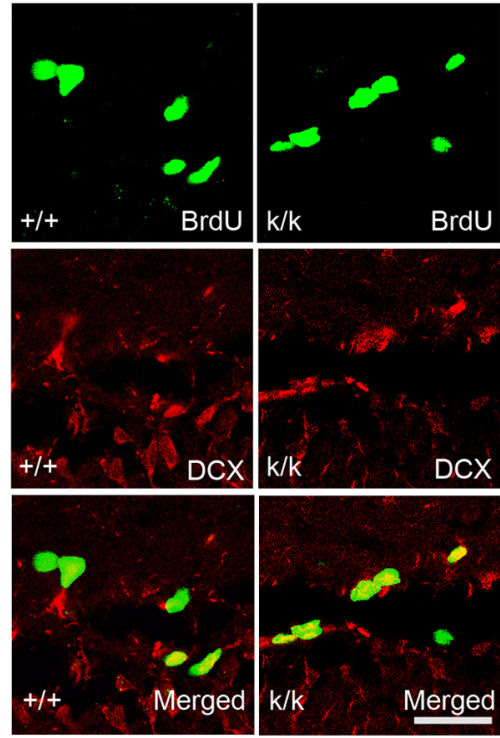

$\mathrm{F}$

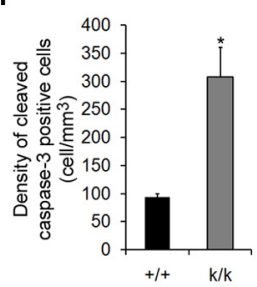

Figure 5. Long 3' UTR Bdnf mRNA promotes differentiation of late stage progenitor cells. A-C, Representative confocal images of BrdU colocalized with Sox2, Tbr2, and DCX in WT (+ /+ ) and Bdnfllox/klox $(\mathrm{k} / \mathrm{k})$ mice. Mice were treated with BrdU at 6 weeks of age and killed $24 \mathrm{~h}$ postinjection for immunohistochemistry. Scale bar, $50 \mu \mathrm{m}$. D, Quantification of BrdU colocalization with Sox2, Tbr2, and DCX. The graph denotes the percentage of BrdU ${ }^{+}$cells that also express one of the markers $(n=3-4$ mice per genotype). Error bars indicate SES. $E$, Representative images of sections that were immunostained for $C(3$ and counterstained with Nissl in $+/+$ and k/kmice. Scale bar, $25 \mu \mathrm{m}$. $\boldsymbol{F}$, Quantification of the density of CC 3 -positive cells in the SGZ of the dentate gyrus of $+/+$ and k/kmice $(n=4$ mice per genotype).SGZ was defined as cells in the first two cell layers of the granule cell layer adjacent to the hilus. Error bars indicate SEs. Student's t test: ${ }^{*} p<0.05 ;{ }^{* *} p<0.01$. 

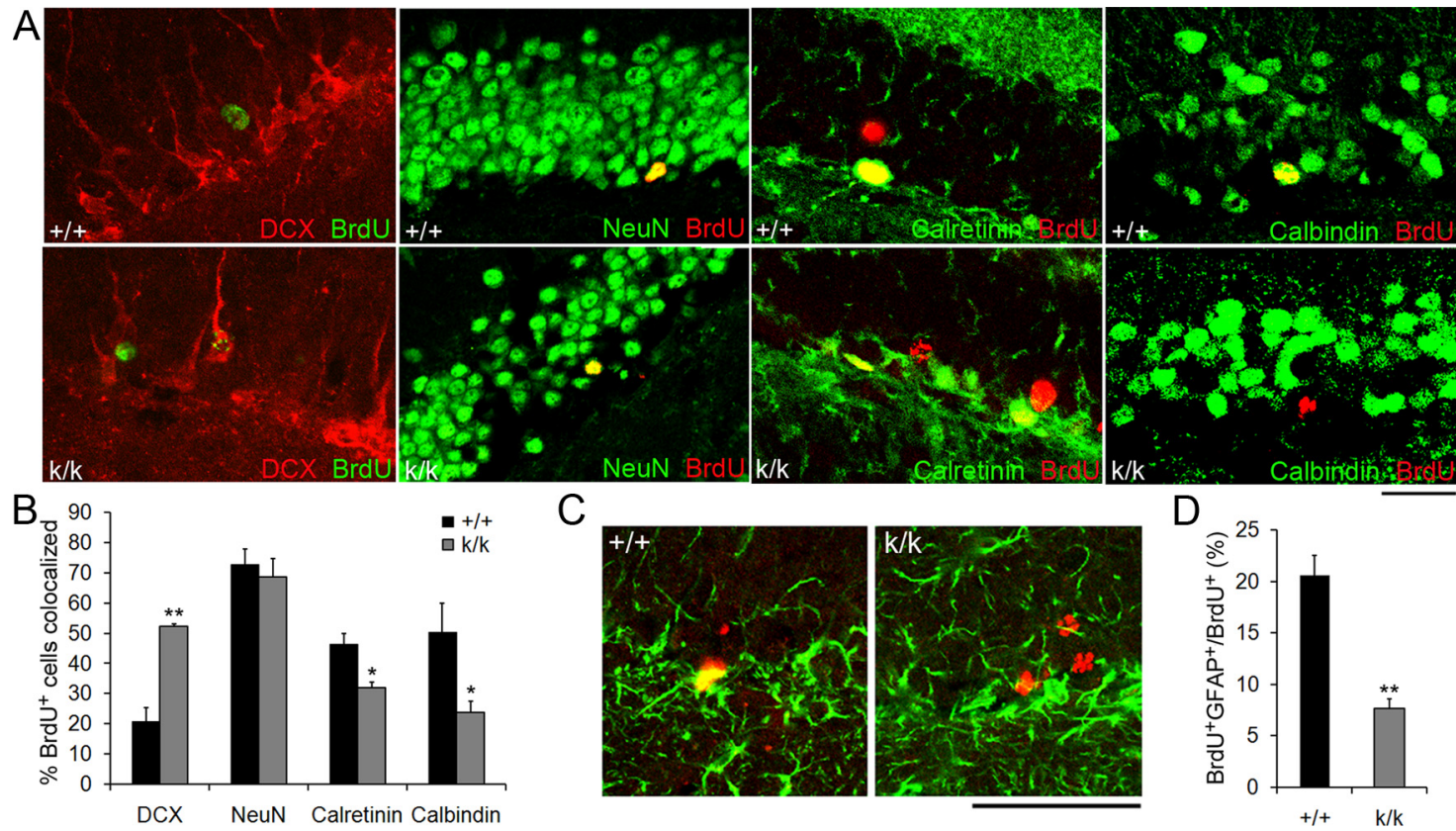

C
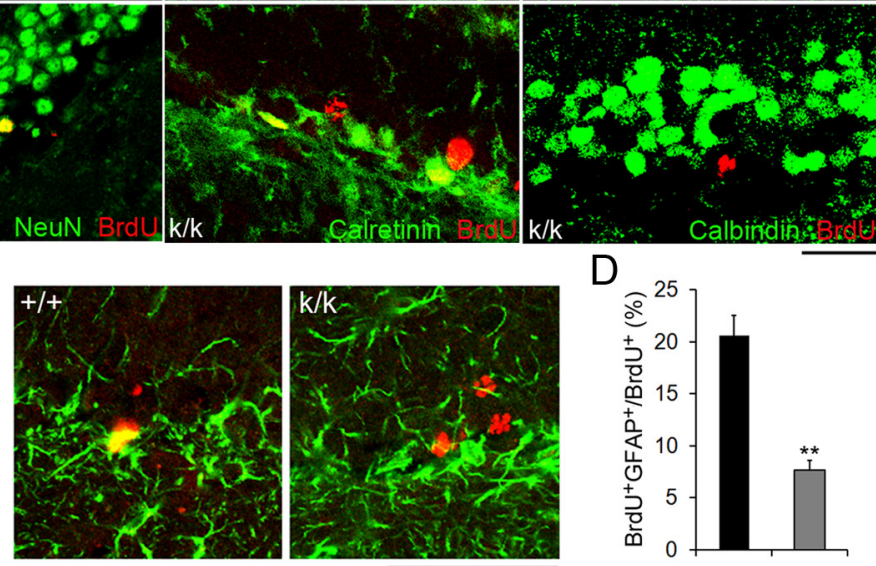

$\mathrm{D}$

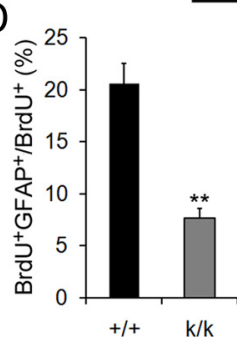

Figure 6. Long 3' UTR Bdnf mRNA facilitates neuronal and glial maturation. $A$, Representative merged confocal images depicting colocalization of BrdU with $D C X$, NeuN, calretinin, or calbindin in WT $(+/+)$ and $B d n f^{k l o x} / k l o x ~(k / k)$ mice. Mice were treated with BrdU at 6 weeks of age and killed 6 weeks post-BrdU injection for immunostaining. Scale bar, $50 \mu \mathrm{m} . \boldsymbol{B}$, Percentage of BrdU ${ }^{+}$cells that were immunoreactive to DCX, NeuN, calretinin, or calbindin 6 weeks post-BrdU injection ( $n=4$ mice per genotype). Error bars indicate SEs. $C$, Representative confocal images of BrdU (red) colocalized with GFAP (green) in $+1+$ and k/k mice. Mice were treated with BrdU at 6 weeks of age and killed 6 weeks post-BrdU injection. Scale bar, $50 \mu \mathrm{m}$. D, Percentage of BrdU ${ }^{+}$cells that expressed GFAP 6 weeks post-BrdU injection ( $n=4$ mice per genotype). Error bars indicate SEs. Student's $t$ test: ${ }^{*} p<0.05 ;{ }^{* *} p<0.01$.

of $\operatorname{Trb} 2^{+}$cells, is upregulated in a compensatory fashion in $B d n f^{k l o x / k l o x}$ mice.

Because $B d n f^{k l o x / k l o x}$ mice did not show expanded BrdU labeling 1-12 weeks post-BrdU administration (Fig. 3B), increased dentate gyrus volume (Fig. $3 C$ ), nor increased granule cell layer volume (Fig. $3 D, E$ ), we sought to determine whether apoptosis was occurring at higher rates in $B d n f^{k l o x / k l o x}$ mice. We stained $B d n f^{\text {klox/klox }}$ and WT sections from 7-week-old mice with an antibody against the apoptotic marker cleaved caspase-3 (CC3) and with cresyl violet to reveal the density of CC3-positive cells in the SGZ (Fig. 5E). Bdnf ${ }^{k l o x / k l o x}$ mice had an increased density of CC3positive cells in the SGZ (Fig. $5 F$ ), indicating increased apoptosis.

\section{Long $3^{\prime}$ UTR $B d n f$ mRNA facilitates neuronal maturation and integration}

To determine whether long $3^{\prime}$ UTR $B d n f$ mRNA is required for normal maturation and integration of adult-born granule cells into the dentate gyrus, we administered BrdU to WT and $B d n f^{k l o x / k l o x}$ mice and waited 6 weeks to allow the newly labeled cells to mature. Sections were then stained with antibodies to BrdU and to one of four markers identifying different stages of granule cell maturation: (1) the microtubule-associated protein DCX, which is expressed early in maturation and marks neuroblasts and immature neurons (Francis et al., 1999; Gleeson et al., 1999); (2) NeuN, which is a soluble nuclear protein and is expressed in both immature and mature neurons (Ming and Song, 2005); (3) calretinin, which is a calcium binding protein and is expressed transiently by immature neurons after DCX expression (Brandt et al., 2003); and, (4) calbindin, which is also a calcium binding protein, is expressed after calretinin, and marks mature granule cells (Brandt et al., 2003). We found that $B d n f^{k l o x / k l o x}$ mice showed increased colocalization of BrdU with the immature neuronal marker DCX and decreased colocalization with the intermediate neuronal marker calretinin and the mature neuronal marker cal- bindin (Fig. $6 A, B$ ). We saw no difference in colocalization of BrdU with NeuN (Fig. $6 A, B$ ), most likely because this population of neurons encompasses some cells expressing DCX and all cells expressing calretinin and calbindin. In a separate experiment, we colocalized GFAP with BrdU 6 weeks after BrdU labeling in WT and $B d n f^{k l o x / k l o x}$ mice. GFAP is expressed in progenitor cells and mature glial cells in the dentate gyrus. We found that 6 weeks after BrdU labeling, significantly fewer BrdU-positive cells expressed GFAP in $B d n f^{k l o x / k l o x}$ mice (Fig. $6 C, D$ ). As the pool of SGZ progenitor cells was not reduced in $B d n f^{k l o x / k l o x}$ mice (Fig. $3 F, G$ ), this result indicates that the lack of long $3^{\prime}$ UTR $B d n f$ mRNA also impairs glial cell maturation. Together, these experiments indicate that long 3' UTR Bdnf mRNA facilitates both neuronal and glial maturation in the dentate gyrus.

Late-phase long-term potentiation and memory consolidation require expression of immediate early genes (Guzowski et al., 2000; Bozon et al., 2002). Two such genes, Arc and Zif268, are induced by activity in newly generated adult-born dentate gyrus neurons (Bruel-Jungerman et al., 2006; Kee et al., 2007). To investigate if adult-born dentate gyrus neurons in $B d n f^{k l o x / k l o x}$ mice show integrational deficits, we used seizure induction to activate the expression of Arc and Zif268 in BrdU-labeled dentate gyrus neurons from WT and $B d n f^{k l o x / k l o x}$ mice (Cole et al., 1990; Snyder et al., 2009). Mice were injected with BrdU at 4 weeks of age, and kept for 4 additional weeks to allow the newly labeled neurons to mature and integrate. At 8 weeks of age, grade $4-5$ seizures were induced using kainate, and animals were killed $2 \mathrm{~h}$ after seizure induction. BrdU-labeled cells that had integrated into the hippocampal circuitry would be more readily activated by this stimulation. Cells that showed strong network integration would contain BrdU and either Arc or Zif268 protein expression $\left(\mathrm{BrdU}^{+} \mathrm{Arc}^{+}\right.$or $\left.\mathrm{BrdU}^{+} \mathrm{Zif} 268^{+}\right)$, while cells that had not strongly integrated would only immunostain for $\mathrm{BrdU}\left(\mathrm{BrdU}^{+}\right)$. We found that $B d n f^{k l o x / k l o x}$ mice had significantly lower levels of 

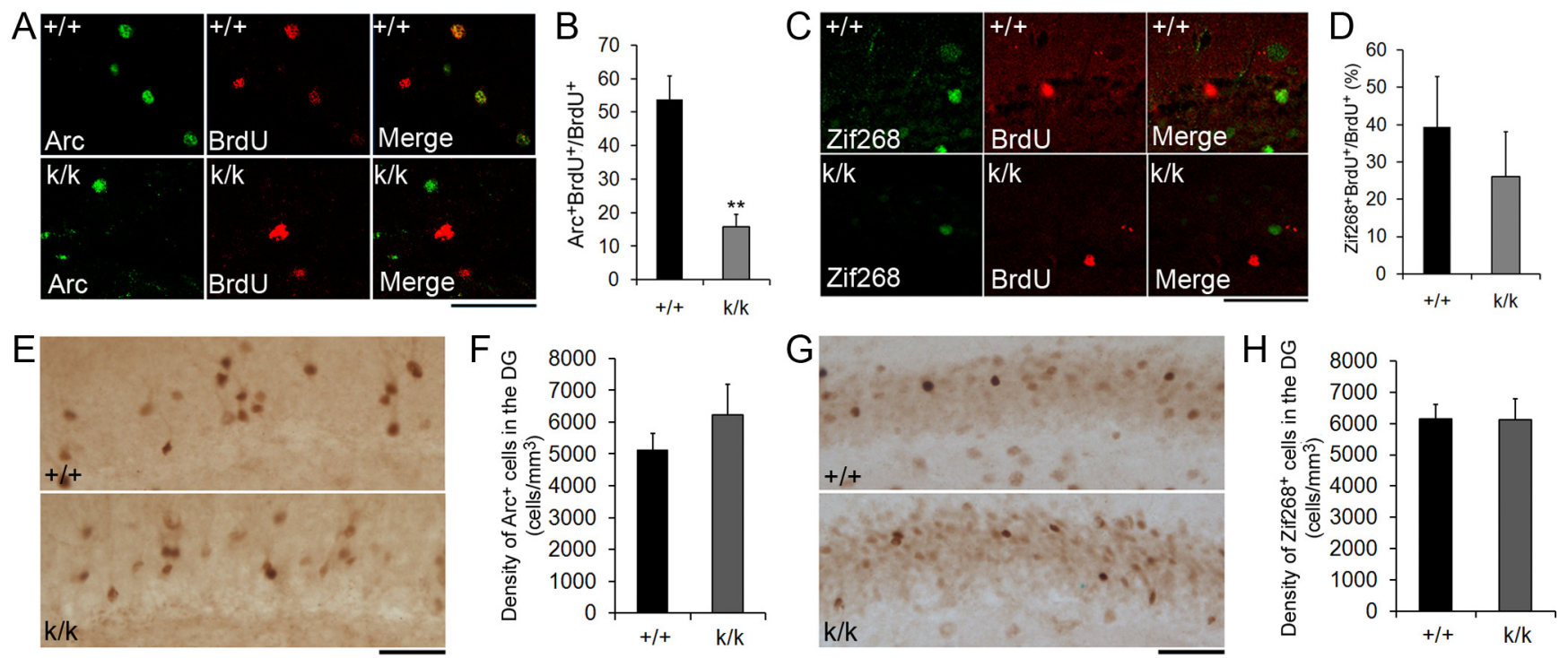

Figure 7. Long 3' UTR Bdnf mRNA facilitates neuronal integration. A, Representative confocal images of activity-dependent Arc expression in adult-born cells. Mice were treated with BrdU at 4 weeks of age. Four weeks post-BrdU injection, kainate $(35 \mathrm{mg} / \mathrm{kg}$, i.p.) was used to induce grade $4-5$ seizures. Two hours postseizure induction, animals were killed for immunohistochemistry. Scale bar, $50 \mu \mathrm{m} . \mathbf{B}$, Percentage of BrdU ${ }^{+}$cells that also expressed Arc 4 weeks post-BrdU injection and $2 \mathrm{~h}$ postseizure induction $(n=3$ mice for $+/+$ and $n=4$ mice for k/k). Error bars indicate SEs. C, Representative confocal images of colocalization of BrdU with Zif268 in the dentate gyrus of $+1+$ and k/k mice. Mice were treated as described in A. Scale bar, $50 \mu \mathrm{m}$. D, Percentage of BrdU ${ }^{+}$ cells that expressed Zif268 4 weeks post-BrdU injection and $2 \mathrm{~h}$ postseizure induction ( $n=3$ mice for $+/+$ and $n=4$ mice for $\mathrm{k} / \mathrm{k}$ ). Error bars indicate SEs. $\boldsymbol{E}$, Representative images of Arc immunohistochemistry in the dentate gyrus of $+/+$ and k/k. Mice were treated as described in $A$. Scale bar, $50 \mu \mathrm{m}$. $F$, Density of Arc ${ }^{+}$cells in the dentate gyrus of $+/+$and k/k mice. Error bars indicate SEs. G, Representative images of Zif268 immunohistochemistry in the dentate gyrus of $+/+$ and k/k mice. Mice were treated as described in $\boldsymbol{A}$. Scale bar, $50 \mu \mathrm{m}$. $\boldsymbol{H}$, Density of Zif268 ${ }^{+}$ cells in the dentate gyrus of $+/+$ and $\mathrm{k} / \mathrm{k}$ mice. Error bars indicate SEs. Student's $t$ test: ${ }^{* *} p<0.01$.

colocalization between Arc and BrdU compared with WT controls (Fig. $7 A, B$ ), demonstrating that fewer adult-born cells had integrated into the hippocampal network in $B d n f^{k l o x / k l o x}$ mice. In addition, although not significant, we saw a trend toward decreased colocalization between Zif268 and BrdU (Fig. 7C,D). This integrational deficit appears to be exclusive to adult-born neurons, because the overall density of Arc and Zif268-positive cells in the dentate gyrus was not significantly different in WT and $B d n f^{k l o x / k l o x}$ mice (Fig. $7 E-H$ ). Collectively, these findings indicate that long $3^{\prime}$ UTR $B d n f$ mRNA facilitates maturation and integration of adult-born neurons.

\section{Long 3' UTR Bdnf mRNA is important for \\ GABAergic transmission}

GABAergic depolarization of progenitor cells regulates neuronal differentiation (Tozuka et al., 2005), maturation, and integration (Ge et al., 2006). Importantly, BDNF has been shown to promote maturation of GABAergic circuitry (Huang et al., 1999) as well as GABA synthesis (Sánchez-Huertas and Rico, 2011). Furthermore, BDNF has been found to facilitate the effects of GABA on adult neurogenesis (Chan et al., 2008). Based on this previous work, we reasoned that the deficits in adult neurogenesis in $B d n f^{k l o x / k l o x}$ mice might be due to altered GABAergic input to the progenitor cell population. To investigate this possibility, we immunostained brain sections from 7-week-old WT and Bdnd ${ }^{k l o x / k l o x}$ mice with antibodies to the presynaptic GABA synthesizing enzyme GAD65 or the presynaptic VGLUT1. We found that $B d n f^{k l o x / k l o x}$ mice had decreased GAD65 staining intensity (Fig. $8 A, B$ ), but normal VGLUT1 staining intensity in the SGZ compared with WT controls (Fig. 8C,D). We also observed a trend toward decreased GAD65 immunoreactivity in the dentate gyrus molecular layer $(100 \pm 4.7 \%$ for WT vs $78.1 \pm 9.8 \%$ for $\left.B d n f^{k l o x / k l o x}, p=0.197\right)$. These results indicate that without long 3' UTR Bdnf mRNA there is deficient GABAe- rgic, but normal glutamatergic innervation to the SGZ. To determine whether the decrease in GAD65 staining intensity in $B d n f^{k l o x / k l o x}$ mice is due to a decrease in the number of GABAergic interneurons, we immunostained brain sections from WT and $B d n f^{k l o x / k l o x}$ mice with antibodies to the interneuron markers PV, SOM, or NPY. We found no significant difference in the density of PV-positive (Fig. 8E,F), SOM-positive (Fig. 8G,H), or NPYpositive (Fig. $8 I, J$ ) cells in the dentate gyrus. These data suggest that long 3' UTR Bdnf mRNA regulates GABAergic transmission to the SGZ, but not interneuron cell number.

\section{Enhancement of $\mathrm{GABA}_{\mathrm{A}}$ receptor activity rescues} neurogenesis deficits in $B d n f^{\text {klox } / k l o x}$ mice $\mathrm{GABA}_{\mathrm{A}}$ receptor signaling stimulates dentate gyrus precursor differentiation into neurons via NeuroD induction (Tozuka et al., 2005). We found that long $3^{\prime}$ UTR $B d n f$ mRNA is required for precursor differentiation and for GABAergic innervation of the SGZ (Figs. 4, 8). We therefore reasoned that decreased GABAergic signaling to the progenitor cell population might impair neuronal differentiation in $B d n f^{k l o x / k l o x}$ mice. To test this, we assessed if $B d n f^{k l o x / k l o x}$ mice had deficits in NeuroD induction in progenitor cells. Twenty-four hours after BrdU administration, we colocalized BrdU and NeuroD in the dentate gyrus of WT and $B d n f^{k l o x / k l o x}$ mice. Progenitor cells that had received GABAergic differentiation signaling would contain both NeuroD and BrdU $\left(\mathrm{NeuroD}^{+} \mathrm{BrdU}^{+}\right)$, whereas cells that had not would only be labeled by $\mathrm{BrdU}\left(\mathrm{BrdU}^{+}\right)$. We found a significantly lower percentage of BrdU-positive cells that also stained for NeuroD in $B d n f^{k l o x / k l o x}$ mice compared with WT controls (Fig. 9A,B), suggesting deficits in GABA-induced differentiation.

To examine whether GABA signaling deficits via the $\mathrm{GABA}_{\mathrm{A}}$ receptor were the cause of the differentiation deficit demonstrated in $B d n f^{g l o x / k l o x}$ mice, we attempted to rescue the neurogenesis deficit in $B d n f^{k l o x / k l o x}$ mice using phenobarbital, a positive 

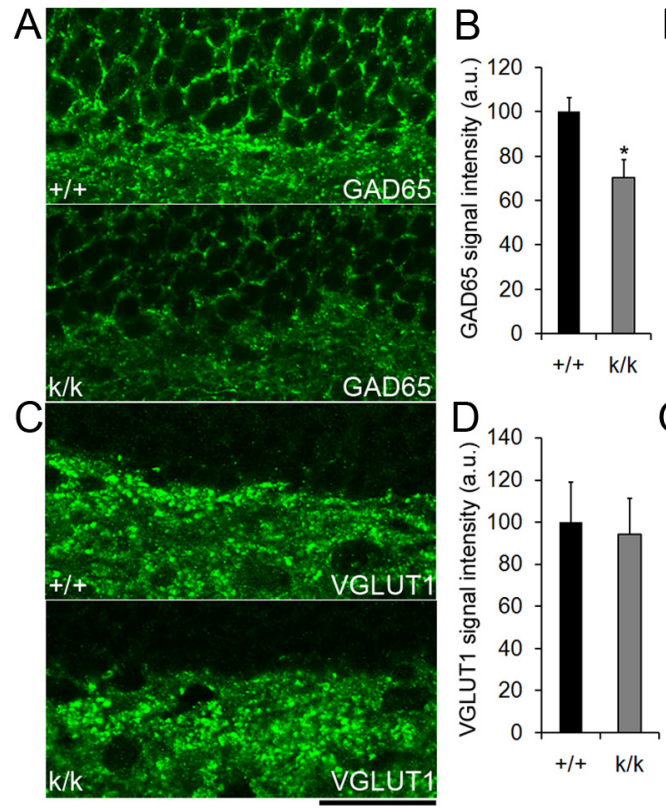

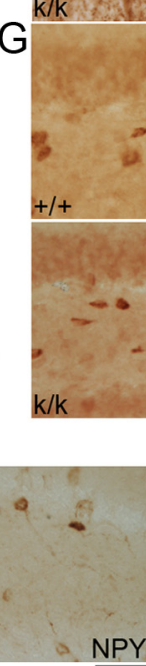

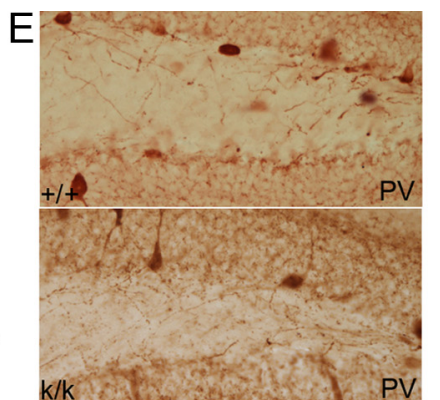

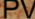

.
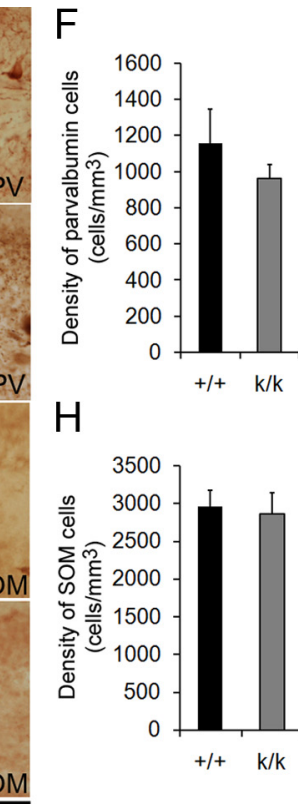

$\mathrm{H}$

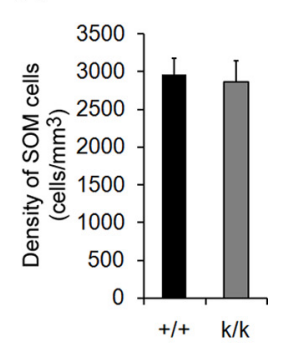

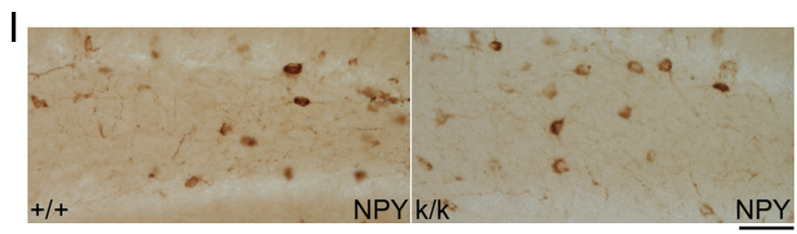

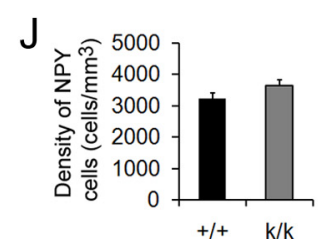

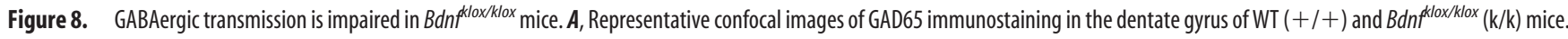
$\boldsymbol{B}$, Quantification of GAD65 immunostaining signal intensity in the SGZ of $+/+$ and k/k mice ( $n=5$ mice per genotype). Error bars indicate SEs. $\boldsymbol{C}$, Representative confocal images of VGLUT1 immunostaining in the dentate gyrus of $+/+$ and k/k mice. Scale bar, $50 \mu \mathrm{m}$. D, Quantification of SGZ VGLUT1 immunostaining signal intensity in $+/+$ and k/k mice ( $n=5$ mice per genotype). Error bars indicate SEs. E-J, Long 3' UTR Bdnf mRNA does not regulate the number of GABAergic interneurons. Representative images show immunohistochemistry against PV, SOM, and NPY in 6-week-old $+/+$ and k/k mice. Normal cell density was found for interneurons expressing PV, SOM, or NPY in the dentate gyrus of 6-week-old k/k mice ( $n=4$ mice per genotype). Error bars indicate SEs. Scale bars, $50 \mu \mathrm{m}$. Student's $t$ test: ${ }^{*} p<0.05$.

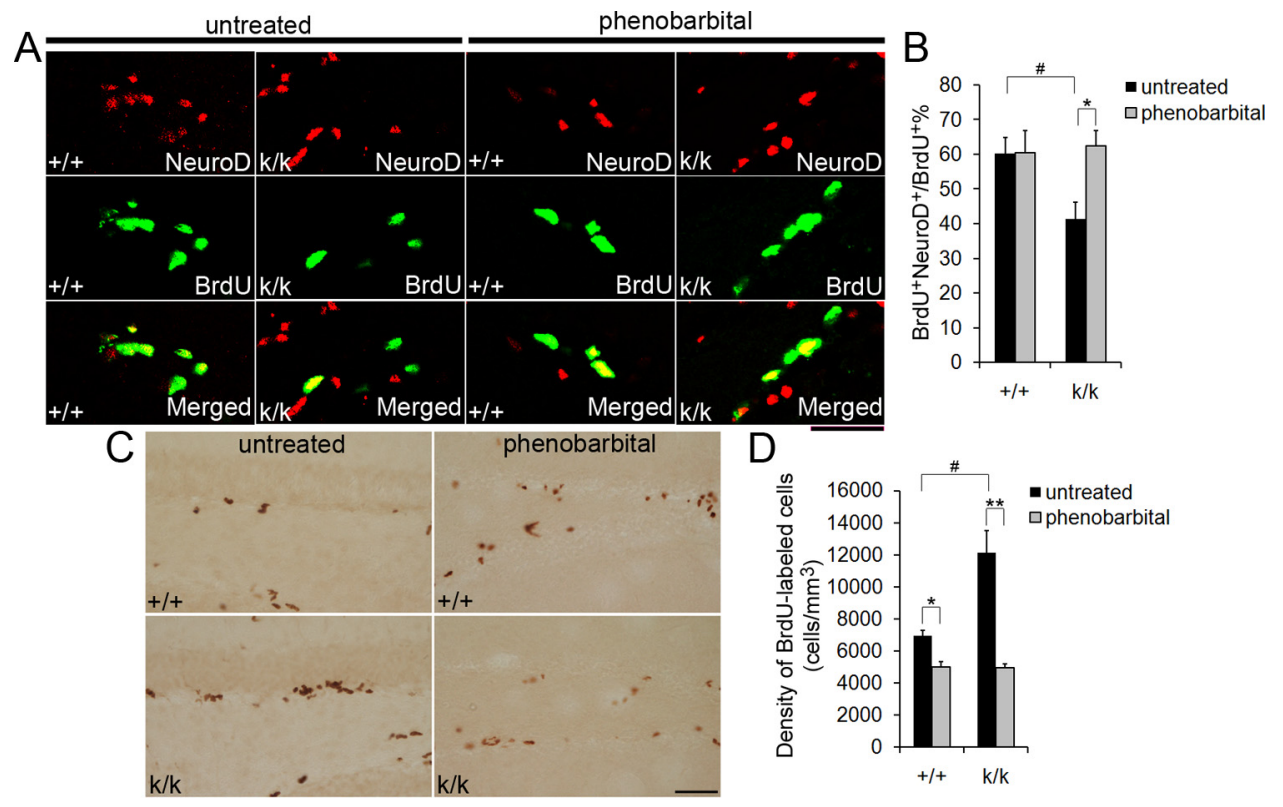

Figure 9. Enhancing $\mathrm{GABA}_{\mathrm{A}}$ receptor activity rescues neurogenesis deficits in Bdnflox/klox mice. $A$, Representative confocal images of immunostaining against BrdU and NeuroD in 6-week-old WT $(+/+)$ and $B d n f^{k l o x / k l o x}(k / k)$ mice, either untreated or treated with phenobarbital. Treated mice were given phenobarbital once a day for $3 \mathrm{~d}$. On the fourth day, treated and untreated mice were given BrdU injections. Mice were killed $24 \mathrm{~h}$ post-BrdU injections. Scale bar, $50 \mu \mathrm{m}$. B, Quantification of colocalization of BrdU with NeuroD in $+/+$ and k/k mice, either untreated or treated with phenobarbital ( $n=4$ mice for untreated groups per genotype; $n=3$ mice for treated groups per genotype). Error bars indicate SEs. $\boldsymbol{C}$, Representative images of BrdU immunostaining in either treated or untreated 6-week-old +/+ or k/k mice. Mice were treated as described in $\boldsymbol{A}$. Scale bar, $50 \mu \mathrm{m}$. D, The density of BrdU ${ }^{+}$cells in the dentate gyrus of untreated and phenobarbital-treated mice, $24 \mathrm{~h}$ following the last BrdU injection ( $n=4$ mice for untreated groups per genotype; $n=3$ mice for treated groups per genotype). Error bars indicate SEs. Student's $t$ test: ${ }^{*}$ or ${ }^{\#} p<0.05$; ${ }^{* *} p<0.01$. 
A

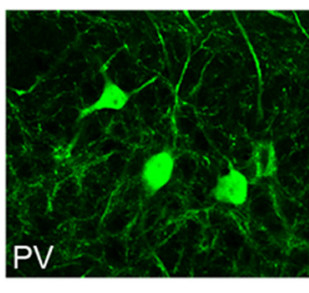

B
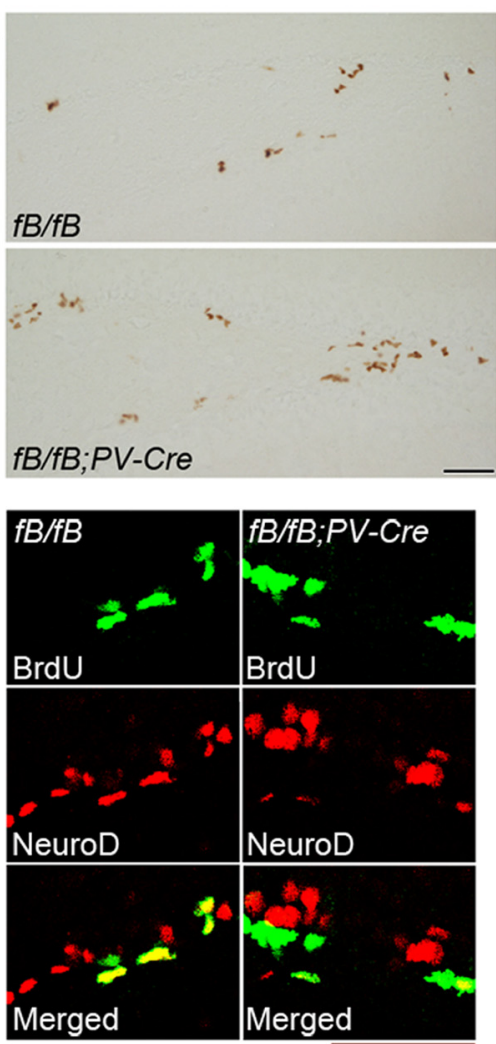

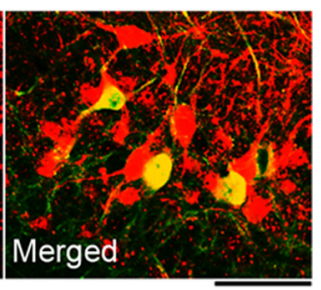

C

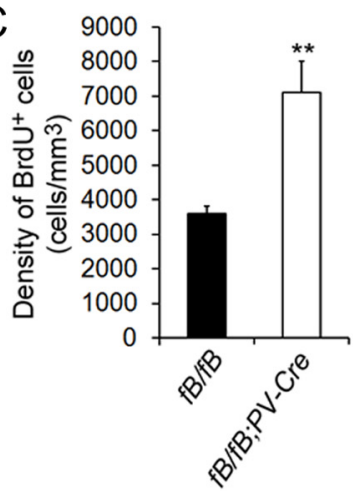

$E$

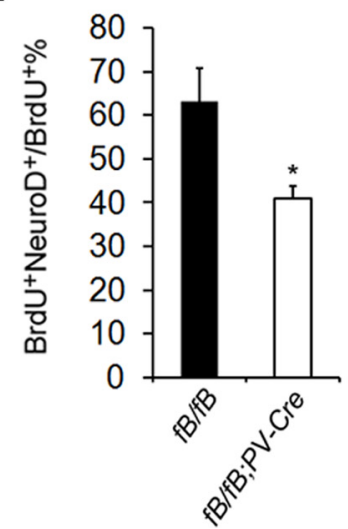

Figure 10. Deletion of the TrkB gene in PV neurons causes neurogenesis deficits. $A$, Confocal images showing colocalization of $\mathrm{PV}$ and TrkB in the dentate gyrus. Sections were taken from $T r k B^{\text {LacZ/+ }}$ mice. Scale bar, $50 \mu \mathrm{m}$. B, Representative images of BrdU immunostaining in 6-week-old $f B / f B$ and $f B / f B ; P V$-Cre mice. Mice were treated with BrdU and killed $24 \mathrm{~h}$ post-BrdU injection. Scale bar, $50 \mu \mathrm{m}$. C, Quantification of BrdU ${ }^{+}$cells in the dentate gyrus of $f B / f B$ and $f B / f B ; P V-C r e$ mice $24 \mathrm{~h}$ post-BrdU administration ( $n=4$ mice per genotype). Error bars indicate SEs. $\boldsymbol{D}$, Representative images of BrdU and NeuroD colocalization in 6-week-old $f B / f B$ and $f B / f B ; P V-C r e$ mice. Mice were treated with BrdU and killed $24 \mathrm{~h}$ post-BrdU injection. Scale bar, $50 \mu \mathrm{m}$. $E$, Quantification of $B r d U^{+}$NeuroD ${ }^{+} / B r d U{ }^{+}$cells in the dentate gyrus of $f B / f B$ and $f B / f B ; P V$-Cre mice $24 \mathrm{~h}$ post-BrdU administration $(n=4$ mice per genotype). Error bars indicate SEs. Student's $t$ test: ${ }^{*} p<0.05$; ${ }^{* *} p<0.01$.

allosteric modulator that increases the average opening time duration of the $\mathrm{GABA}_{\mathrm{A}}$ receptor. Based on an established protocol (Tozuka et al., 2005), we gave 6-week-old WT and $B d n f^{\text {klox/klox }}$ mice phenobarbital systemically once a day for $3 \mathrm{~d}$, and on the fourth day administered BrdU. Twenty-four hours post-BrdU administration, the animals were killed and their brains were prepared for immunohistochemistry with antibodies to BrdU and NeuroD. Remarkably, phenobarbital administration restored WT levels of NeuroD and BrdU colocalization in $B d n f^{\text {klox/klox }}$ mice (Fig. $9 A, B$ ), demonstrating that activation of the $\mathrm{GABA}_{\mathrm{A}}$ receptor is sufficient to rescue the impaired differentiation phenotype observed in $B d n f^{k l o x / k l o x}$ mice.

Similarly, we hypothesized that if $\mathrm{GABA}_{\mathrm{A}}$ receptor signaling is working downstream of dendritic BDNF to stimulate neuronal differentiation, then phenobarbital administration would also rescue the phenotype of increased $24 \mathrm{~h} \mathrm{BrdU}$ labeling in $B d n f^{k l o x / k l o x}$ mice (Fig. $3 B$ ). Indeed, we found that phenobarbital treatment normalized the

density of BrdU-labeled cells in the dentate gyrus of $B d n f^{\text {klox/klox }}$ mice to treated WT levels (Fig. 9C,D). Our finding that phenobarbital administration significantly reduced the density of BrdU-labeled cells in the dentate gyrus of WT mice (Fig. 9D) is consistent with a previous report that GABA modulates neuronal differentiation in WT mice (Tozuka et al., 2005). Collectively, these data suggest that long $3^{\prime}$ UTR Bdnf mRNA stimulates differentiation of progenitor cells via $\mathrm{GABA}_{\mathrm{A}}$ receptor signaling.

\section{Deletion of the TrkB gene in PV- expressing interneurons causes neurogenesis deficits}

The dentate gyrus has multiple subtypes of GABAergic interneurons, which have been classified based on morphology, electrophysiology, and expression of calcium-binding proteins and neuropeptides (Houser, 2007). PV interneurons are GABAergic basket cells of the dentate gyrus and comprise $20-25 \%$ of the total dentate gyrus interneuron population (Jinno and Kosaka, 2002). Since PV neurons form perisomatic GABAergic synapses (Freund, 2003) and their maturation and action potential firing are stimulated by BDNF (Huang et al., 1999; Berghuis et al., 2004), we hypothesized that PV neurons might provide the pathway through which BDNF derived from long 3' UTR Bdnf mRNA promotes differentiation and maturation of neural precursor cells.

First we investigated whether TrkB is expressed in PV interneurons of the dentate gyrus, and therefore could be stimulated by BDNF derived from long 3' UTR Bdnf mRNA. We performed immunohistochemistry against $\mathrm{PV}$ and $\beta$ galactosidase on brain sections from $\operatorname{Trk} B^{\operatorname{Lac} Z /+}$ mice where expression of $\beta$-galactosidase is under the control of the $\operatorname{TrkB}$ promoter and thus recapitulates the expression pattern of the $\operatorname{TrkB}$ gene (Xu et al., 2000b), and found that $100 \%$ of PV-positive neurons expressed TrkB (Fig. 10A). On the contrary, we found that dentate gyrus PV interneurons did not express BDNF (data not shown).

Next, we used Parvalbumin-Cre (PV-Cre) mice (Tanahira et al., 2009) and floxed TrkB ( $f B$ ) mice (Baydyuk et al., 2011) to selectively delete the $\operatorname{TrkB}$ gene in PV-expressing cells. It has been demonstrated that the TrkB gene is efficiently deleted in $\mathrm{PV}$ interneurons of $f B / f B ; P V$-Cre mice (Zheng et al., 2011). We hypothesized that $f B / f B ; P V$-Cre mutant mice would display an impaired neurogenesis phenotype similar to that found in $B d n f^{k l o x / k l o x}$ mice. To investigate this possibility, we injected $f B / f B$ (control) mice and $f B / f B ; P V$-Cre mice with BrdU and killed the animals $24 \mathrm{~h}$ later for immunohistochemistry with antibodies to BrdU. We found that similar to $B d n f^{k l o x / k l o x}$ mice, $f B / f B ; P V$-Cre mice had a $97 \%$ increase in BrdU-labeled cells compared with control mice (Fig. 10B,C). We then examined 
whether these mice also exhibited deficits in GABA-induced differentiation by colocalizing BrdU with NeuroD in sections taken from $f B / f B$ and $f B / f B ; P V$-Cre mice that had been injected with BrdU 24 h earlier. We found that, similar to $B d n f^{k l o x / k l o x}$ mice, $f B / f B ; P V$-Cre mice had decreased NeuroD expression in newborn cells, suggesting deficits in neuronal differentiation (Fig. 10D,E). To examine whether TrkB deletion in PV neurons affects interneuron survival, we immunostained sections from $f B / f B$ and $f B / f B ; P V$-Cre mice with an antibody to PV to determine the density of PV neurons in the dentate gyrus. We found no significant difference in the density of PV neurons between genotypes (1096 \pm 62 cells $/ \mathrm{mm}^{3}$ for $f B / f B$ mice vs $1154 \pm 121$ cells $/ \mathrm{mm}^{3}$ for $f B / f B ; P V$-Cre, $p=0.683, n=4$ mice per genotype), indicating that the observed increase in BrdU-labeled cells and the deficit in NeuroD expression in adult-born cells were due to functional deficits of PV neurons. Together, these data suggest that BDNF from granule cells acts on the TrkB receptor on PV interneurons to regulate adult neurogenesis in the dentate gyrus.

\section{Discussion}

We found that $B d n f^{k l o x / k l o x}$ mice displayed increased proliferation, decreased differentiation, decreased maturation, and decreased integration of adult-born neuronal precursors in the dentate gyrus. As new cells differentiate and mature, they have unique electrophysiological, biochemical, and morphological properties. Thus, altering the time frame of their cellular maturation would likely significantly impact hippocampal function. Much work has been dedicated to understanding the role of adult-born neurons in hippocampal function, with recent studies showing that specific suppression or depletion of dentate gyrus progenitor cells led to deficits in fine-tuned spatial discrimination, but not other hippocampal-dependent tasks (Dupret et al., 2008; Zhang et al., 2008). It is likely that $B d n n^{\text {klox/klox }}$ mice have deficits in fine-tuned spatial discrimination; however, these animals lack long 3' UTR Bdnf mRNA throughout the whole brain, which makes it difficult to examine neurogenesis-dependent behavior in this mouse strain.

Our results show that $B d n f^{\text {klox/klox }}$ mice lack dendritic $B d n f$ mRNA and thus are deficient in dendritic BDNF synthesis in dentate gyrus granule cells, due to a truncation of the long $B d n f 3^{\prime}$ UTR. Additionally, these animals also have a $48 \%$ reduction in total BDNF levels in the hippocampus compared with WT mice. As activity stimulates translation of long $3^{\prime}$ UTR Bdnf mRNA and suppresses translation of short 3' UTR Bdnf mRNA (Lau et al., 2010), the loss of the long $B d n f 3^{\prime}$ UTR may diminish activity-dependent translation of $B d n f$ mRNA and therefore reduce total BDNF levels in $B d n f^{k l o x} / k l o x$ mice. Even though $B d n f^{k l o x / k l o x}$ mice have decreased total BDNF levels, this adult neurogenesis phenotype likely resulted from a lack of dendritic BDNF synthesis rather than decreased total BDNF levels, because $B d n f^{+/-}$mice did not display neurogenesis deficits. Local protein synthesis in dendrites has been shown to be crucial for lasting long-term potentiation and long-term depression in hippocampal slices (Bramham and Wells, 2007; Waterhouse and Xu, 2009). Our results provide evidence that local protein synthesis may also modulate synaptic plasticity of hippocampal neural circuitry by regulating adult neurogenesis. However, we did find that the reduction in total BDNF levels was slightly more severe in Bdnflox/klox mice (48\%) than $B d n f^{+/-}$mice $(36 \%)$. We do not know if the additional decrease in total BDNF levels would also contribute to the observed increase in proliferation of progenitor cells in the SGZ of $B d n f^{g l o x / k l o x}$ mice.

Similar to our findings in $B d n f^{k l o x / k l o x}$ mice, deletion of the $B d n f$ gene in mature or nearly mature neurons, using a Cre trans- gene under the control of the promoter for the $\alpha$-subunit of $\mathrm{Ca}^{2+} /$ calmodulin-dependent protein kinase II (CaMKII $\left.\alpha\right)$, led to an increase in BrdU-labeled cells $1 \mathrm{~d}$ post-BrdU injection, as well as impaired maturation of adult-born neurons (Chan et al., 2008). Our study was able to further demonstrate that the observed increase in proliferation was due to impaired differentiation of progenitor cells, and that these accumulating adult-born cells eventually undergo apoptosis within the first week after division and labeling. In support of this idea, using antibodies to scavenge BDNF in vitro led to decreased neuronal differentiation of progenitor cells (Babu et al., 2009). The close resemblance in the adult neurogenesis phenotype between $B d n f^{k l o x / k l o x}$ mice and CaMKII $\alpha$-Cre-mediated Bdnf conditional mutants indicates that the role of BDNF in the differentiation and maturation of adultborn neurons is primarily mediated by BDNF synthesized in the dendrites of mature neurons. This finding suggests that BDNF synthesized in different cell types and/or subcellular compartments may have distinct roles in adult neurogenesis. For example, deletion of the $B d n f$ or $\operatorname{TrkB}$ gene in progenitor cells was found to decrease proliferation of these cells and reduce dentate gyrus thickness (Li et al., 2008), a phenotype not observed in $B d n f^{k l o x / k l o x}$ mice or CaMKII $\alpha$-Cre-mediated Bdnf conditional mutants (Chan et al., 2008). This suggests that total BDNF expression in progenitor cells is necessary for proliferation of progenitor cells and maintenance of dentate gyrus volume, whereas BDNF synthesized in the dendrites of mature neurons regulates differentiation and maturation of adult-born neurons. The complex regulation of adult hippocampal neurogenesis by BDNF may explain why nonselective BDNF application or removal, such as BDNF infusion and deletion of one copy of the $B d n f$ gene, has produced conflicting results (Lee et al., 2002a; Sairanen et al., 2005; Scharfman et al., 2005).

BDNF regulates inhibitory synaptic transmission both in vitro and in vivo. In vitro, BDNF has been shown to facilitate several aspects of inhibitory transmission, including GABA synthesis, neurite outgrowth, and synaptic inhibitory strength (Widmer and Hefti, 1994; Marty et al., 1996; Rutherford et al., 1997; Sánchez-Huertas and Rico, 2011). In vivo, BDNF has been shown to promote maturation of GABAergic inhibitory networks in the visual cortex (Huang et al., 1999), and without activity-dependent BDNF synthesis, cortical inhibitory networks show decreased spontaneous inhibitory events, decreased inhibitory synapses, and decreased expression of presynaptic inhibitory markers (Hong et al., 2008; Sakata et al., 2009). Furthermore, activation of $\mathrm{GABA}_{\mathrm{A}}$ receptors on dentate gyrus progenitor cells stimulates differentiation and maturation of these cells into the neuronal phenotype (Tozuka et al., 2005; Ge et al., 2006). These findings suggest that dendritically synthesized BDNF may regulate differentiation and maturation of progenitor cells by modulating GABAergic transmission in the SGZ. To this end, Chan et al. (2008) reported that in CaMKII-Cremediated $B d n f$ conditional knock-outs, blockade of $\mathrm{GABA}_{\mathrm{A}}$ receptors failed to increase $24 \mathrm{~h}$ proliferation of dentate gyrus progenitor cells, suggesting that BDNF facilitates the effect of GABA on progenitor cell proliferation. Our work further indicates that dendritic BDNF is modulating GABA-mediated control of adult neurogenesis via presynaptic mechanisms, and that the increase in proliferation is actually due to deficits in cell cycle exit and neuronal differentiation. We conclude this based on the reduced GAD65 immunoreactivity observed in the SGZ of $B d n f^{k l o x / k l o x}$ mice, and importantly because we were able to rescue the proliferation and differentiation phenotype observed in $B d n f^{\text {klox/klox }}$ mice with systemic application of phenobarbital. 
Interestingly, $f B / f B ; P V$-Cre mice displayed similar adult neurogenesis phenotypes to $B d n f^{k l o x / k l o x}$ mice, such as increased proliferation and decreased differentiation. This observation leads us to believe that dendritically synthesized BDNF regulates GABAergic synaptic transmission in the SGZ by binding to TrkB receptors on PV interneurons. This observation also further indicates that BDNF crucial for differentiation and maturation of adultborn neurons comes from mature granule cells, because newborn granule cells only constitute a small fraction of dentate gyrus neurons and may not produce a sufficient amount of BDNF to have a significant impact on PV interneurons. TrkB-mediated signaling cascades may boost GABAergic synaptic transmission in interneurons through several mechanisms, including promoting dendritic growth and thus increasing the dendritic receptive field, enhancing the efficacy of excitatory inputs to interneurons, increasing GABAergic terminal innervation of the SGZ, and facilitating GABA synthesis and release. Activation of transcriptional programs in the cell bodies of interneurons by BDNF-TrkB signaling may be required to alter GABAergic synaptic transmission into the SGZ. Since dendrites contain components necessary for endocytosis and retrograde transport (Kennedy and Ehlers, 2006; Kapitein et al., 2010), one way for dendritically synthesized $\mathrm{BDNF}$ to activate signaling cascades in cell bodies might be through the transport of BDNF-TrkB complexes from dendrites to cell bodies; a mechanism similar to retrograde neurotrophic signaling in axons (Cosker et al., 2008). In support of this possibility, recent in vitro work demonstrated that BDNF-TrkB signaling increased GAD65 transcription via CREB signaling (Sánchez-Huertas and Rico, 2011). Further investigation is needed to elucidate how dendritically synthesized BDNF alters GABAergic synaptic transmission in the neurogenic niche.

In conclusion, we have presented evidence that supports a model in which release of locally synthesized BDNF from dendrites of mature granule cells may stimulate TrkB receptors on GABAergic interneurons, likely PV-expressing neurons, to increase GABA input to neural precursors, thus stimulating their differentiation and maturation into neurons. In addition, these data provide evidence for a possible mechanism by which GABAergic stimulation of the neurogenic niche is regulated.

\section{References}

An JJ, Gharami K, Liao GY, Woo NH, Lau AG, Vanevski F, Torre ER, Jones KR, Feng Y, Lu B, Xu B (2008) Distinct role of long 3' UTR BDNF mRNA in spine morphology and synaptic plasticity in hippocampal neurons. Cell 134:175-187.

Babu H, Ramirez-Rodriguez G, Fabel K, Bischofberger J, Kempermann G (2009) Synaptic network activity induces neuronal differentiation of adult hippocampal precursor cells through BDNF signaling. Front Neurosci 3:49.

Baydyuk M, Russell T, Liao GY, Zang K, An JJ, Reichardt LF, Xu B (2011) TrkB receptor controls striatal formation by regulating the number of newborn striatal neurons. Proc Natl Acad Sci U S A 108:1669-1674.

Bergami M, Rimondini R, Santi S, Blum R, Götz M, Canossa M (2008) Deletion of TrkB in adult progenitors alters newborn neuron integration into hippocampal circuits and increases anxiety-like behavior. Proc Natl Acad Sci U S A 105:15570-15575.

Berghuis P, Dobszay MB, Sousa KM, Schulte G, Mager PP, Härtig W, Görcs TJ, Zilberter Y, Ernfors P, Harkany T (2004) Brain-derived neurotrophic factor controls functional differentiation and microcircuit formation of selectively isolated fast-spiking GABAergic interneurons. Eur J Neurosci 20:1290-1306.

Bozon B, Davis S, Laroche S (2002) Regulated transcription of the immediate-early gene Zif268: mechanisms and gene dosage-dependent function in synaptic plasticity and memory formation. Hippocampus 12:570-577.

Bramham CR, Wells DG (2007) Dendritic mRNA: transport, translation and function. Nat Rev Neurosci 8:776-789.
Brandt MD, Jessberger S, Steiner B, Kronenberg G, Reuter K, Bick-Sander A, von der Behrens W, Kempermann G (2003) Transient calretinin expression defines early postmitotic step of neuronal differentiation in adult hippocampal neurogenesis of mice. Mol Cell Neurosci 24:603-613.

Bruel-Jungerman E, Davis S, Rampon C, Laroche S (2006) Long-term potentiation enhances neurogenesis in the adult dentate gyrus. J Neurosci 26:5888-5893.

Chan JP, Cordeira J, Calderon GA, Iyer LK, Rios M (2008) Depletion of central BDNF in mice impedes terminal differentiation of new granule neurons in the adult hippocampus. Mol Cell Neurosci 39:372-383.

Cole AJ, Abu-Shakra S, Saffen DW, Baraban JM, Worley PF (1990) Rapid rise in transcription factor mRNAs in rat brain after electroshock-induced seizures. J Neurochem 55:1920-1927.

Cosker KE, Courchesne SL, Segal RA (2008) Action in the axon: generation and transport of signaling endosomes. Curr Opin Neurobiol 18:270-275.

Dupret D, Revest JM, Koehl M, Ichas F, De Giorgi F, Costet P, Abrous DN, Piazza PV (2008) Spatial relational memory requires hippocampal adult neurogenesis. PLoS One 3:e1959.

Francis F, Koulakoff A, Boucher D, Chafey P, Schaar B, Vinet MC, Friocourt G, McDonnell N, Reiner O, Kahn A, McConnell SK, Berwald-Netter Y, Denoulet P, Chelly J (1999) Doublecortin is a developmentally regulated, microtubule-associated protein expressed in migrating and differentiating neurons. Neuron 23:247-256.

Freund TF (2003) Interneuron diversity series: rhythm and mood in perisomatic inhibition. Trends Neurosci 26:489-495.

Ge S, Goh EL, Sailor KA, Kitabatake Y, Ming GL, Song H (2006) GABA regulates synaptic integration of newly generated neurons in the adult brain. Nature 439:589-593.

Ghosh A, Carnahan J, Greenberg ME (1994) Requirement for BDNF in activity-dependent survival of cortical neurons. Science 263:1618-1623.

Gleeson JG, Lin PT, Flanagan LA, Walsh CA (1999) Doublecortin is a microtubule-associated protein and is expressed widely by migrating neurons. Neuron 23:257-271.

Guzowski JF, Lyford GL, Stevenson GD, Houston FP, McGaugh JL, Worley PF, Barnes CA (2000) Inhibition of activity-dependent arc protein expression in the rat hippocampus impairs the maintenance of long-term potentiation and the consolidation of long-term memory. J Neurosci 20:3993-4001.

Hong EJ, McCord AE, Greenberg ME (2008) A biological function for the neuronal activity-dependent component of Bdnf transcription in the development of cortical inhibition. Neuron 60:610-624.

Houser CR (2007) Interneurons of the dentate gyrus: an overview of cell types, terminal fields and neurochemical identity. Prog Brain Res 163:217-232.

Huang EJ, Reichardt LF (2001) Neurotrophins: roles in neuronal development and function. Annu Rev Neurosci 24:677-736.

Huang ZJ, Kirkwood A, Pizzorusso T, Porciatti V, Morales B, Bear MF, Maffei L, Tonegawa S (1999) BDNF regulates the maturation of inhibition and the critical period of plasticity in mouse visual cortex. Cell 98:739-755.

Jinno S, Kosaka T (2002) Patterns of expression of calcium binding proteins and neuronal nitric oxide synthase in different populations of hippocampal GABAergic neurons in mice. J Comp Neurol 449:1-25.

Kapitein LC, Schlager MA, Kuijpers M, Wulf PS, van Spronsen M, MacKintosh FC, Hoogenraad CC (2010) Mixed microtubules steer dyneindriven cargo transport into dendrites. Curr Biol 20:290-299.

Kee N, Teixeira CM, Wang AH, Frankland PW (2007) Preferential incorporation of adult-generated granule cells into spatial memory networks in the dentate gyrus. Nat Neurosci 10:355-362.

Kennedy MJ, Ehlers MD (2006) Organelles and trafficking machinery for postsynaptic plasticity. Annu Rev Neurosci 29:325-362.

Lau AG, Irier HA, Gu J, Tian D, Ku L, Liu G, Xia M, Fritsch B, Zheng JQ, Dingledine R, Xu B, Lu B, Feng Y (2010) Distinct 3'UTRs differentially regulate activity-dependent translation of brain-derived neurotrophic factor (BDNF). Proc Natl Acad Sci U S A 107:15945-15950.

Lee J, Seroogy KB, Mattson MP (2002a) Dietary restriction enhances neurotrophin expression and neurogenesis in the hippocampus of adult mice. J Neurochem 80:539-547.

Lee J, Duan W, Mattson MP (2002b) Evidence that brain-derived neurotrophic factor is required for basal neurogenesis and mediates, in part, the enhancement of neurogenesis by dietary restriction in the hippocampus of adult mice. J Neurochem 82:1367-1375.

Li Y, Luikart BW, Birnbaum S, Chen J, Kwon CH, Kernie SG, Bassel-Duby R, 
Parada LF (2008) TrkB regulates hippocampal neurogenesis and governs sensitivity to antidepressive treatment. Neuron 59:399-412.

Marty S, Berninger B, Carroll P, Thoenen H (1996) GABAergic stimulation regulates the phenotype of hippocampal interneurons through the regulation of brain-derived neurotrophic factor. Neuron 16:565-570.

Ming GL, Song H (2005) Adult neurogenesis in the mammalian central nervous system. Annu Rev Neurosci 28:223-250.

Ming GL, Song H (2011) Adult neurogenesis in the mammalian brain: significant answers and significant questions. Neuron 70:687-702.

Patterson SL, Grover LM, Schwartzkroin PA, Bothwell M (1992) Neurotrophin expression in rat hippocampal slices: a stimulus paradigm inducing LTP in CA1 evokes increases in BDNF and NT-3 mRNAs. Neuron 9:1081-1088.

Racine RJ, Gartner JG, Burnham WM (1972) Epileptiform activity and neural plasticity in limbic structures. Brain Res 47:262-268.

Rutherford LC, DeWan A, Lauer HM, Turrigiano GG (1997) Brain-derived neurotrophic factor mediates the activity-dependent regulation of inhibition in neocortical cultures. J Neurosci 17:4527-4535.

Sairanen M, Lucas G, Ernfors P, Castrén M, Castrén E (2005) Brain-derived neurotrophic factor and antidepressant drugs have different but coordinated effects on neuronal turnover, proliferation, and survival in the adult dentate gyrus. J Neurosci 25:1089-1094.

Sakata K, Woo NH, Martinowich K, Greene JS, Schloesser RJ, Shen L, Lu B (2009) Critical role of promoter IV-driven BDNF transcription in GABAergic transmission and synaptic plasticity in the prefrontal cortex. Proc Natl Acad Sci U S A 106:5942-5947.

Sala C, Rudolph-Correia S, Sheng M (2000) Developmentally regulated NMDA receptor-dependent dephosphorylation of cAMP response element-binding protein (CREB) in hippocampal neurons. J Neurosci 20:3529-3536.

Sánchez-Huertas C, Rico B (2011) CREB-dependent regulation of GAD65 transcription by BDNF/TrkB in cortical interneurons. Cereb Cortex 21:777-788.

Scharfman H, Goodman J, Macleod A, Phani S, Antonelli C, Croll S (2005) Increased neurogenesis and the ectopic granule cells after intrahippocampal BDNF infusion in adult rats. Exp Neurol 192:348-356.

Snyder JS, Glover LR, Sanzone KM, Kamhi JF, Cameron HA (2009) The effects of exercise and stress on the survival and maturation of adultgenerated granule cells. Hippocampus 19:898-906.

Tanahira C, Higo S, Watanabe K, Tomioka R, Ebihara S, Kaneko T, Tamamaki N (2009) Parvalbumin neurons in the forebrain as revealed by parvalbumin-Cre transgenic mice. Neurosci Res 63:213-223.

Timmusk T, Palm K, Metsis M, Reintam T, Paalme V, Saarma M, Persson H (1993) Multiple promoters direct tissue-specific expression of the rat BDNF gene. Neuron 10:475-489.

Tozuka Y, Fukuda S, Namba T, Seki T, Hisatsune T (2005) GABAergic excitation promotes neuronal differentiation in adult hippocampal progenitor cells. Neuron 47:803-815.

Waterhouse EG, Xu B (2009) New insights into the role of brain-derived neurotrophic factor in synaptic plasticity. Mol Cell Neurosci 42:81-89.

Widmer HR, Hefti F (1994) Stimulation of GABAergic neuron differentiation by NT- $4 / 5$ in cultures of rat cerebral cortex. Brain Res Dev Brain Res 80:279-284.

Xu B, Zang K, Ruff NL, Zhang YA, McConnell SK, Stryker MP, Reichardt LF (2000a) Cortical degeneration in the absence of neurotrophin signaling: dendritic retraction and neuronal loss after removal of the receptor TrkB. Neuron 26:233-245.

Xu B, Gottschalk W, Chow A, Wilson RI, Schnell E, Zang K, Wang D, Nicoll RA, Lu B, Reichardt LF (2000b) The role of brain-derived neurotrophic factor receptors in the mature hippocampus: modulation of long-term potentiation through a presynaptic mechanism involving TrkB. J Neurosci 20:6888-6897.

Xu B, Goulding EH, Zang K, Cepoi D, Cone RD, Jones KR, Tecott LH, Reichardt LF (2003) Brain-derived neurotrophic factor regulates energy balance downstream of melanocortin-4 receptor. Nat Neurosci 6:736-742.

Zhang CL, Zou Y, He W, Gage FH, Evans RM (2008) A role for adult TLXpositive neural stem cells in learning and behaviour. Nature 451: 1004-1007.

Zhao C, Deng W, Gage FH (2008) Mechanisms and functional implications of adult neurogenesis. Cell 132:645-660.

Zheng K, An JJ, Yang F, Xu W, Xu ZQ, Wu J, Hökfelt TG, Fisahn A, Xu B, Lu $B$ (2011) TrkB signaling in parvalbumin-positive interneurons is critical for gamma-band network synchronization in hippocampus. Proc Natl Acad Sci U S A 108:17201-17206. 